\title{
Mineral Carbonation as an Educational Investigation of Green Chemical Engineering Design
}

\author{
Hugo Fantucci ${ }^{1}$, Jaspreet S. Sidhu ${ }^{2}$ and Rafael M. Santos ${ }^{1,2, * \mathbb{C}}$ \\ 1 School of Engineering, University of Guelph, Guelph, ON N1G 2W1, Canada \\ 2 School of Applied Chemical and Environmental Sciences, \\ Sheridan College Institute of Technology and Advanced Learning, Brampton, ON L6Y 5H9, Canada \\ * Correspondence: santosr@uoguelph.ca; Tel.: +1-519-824-4120 (Ext. 52902)
}

Received: 7 July 2019; Accepted: 24 July 2019; Published: 1 August 2019

\begin{abstract}
Engaging students in the experimental design of "green" technology is a challenge in Chemical Engineering undergraduate programs. This concept paper demonstrates an educational methodology to investigate accelerated mineral carbonation, which is a promising technology related to mitigation of climate change by sequestering carbon dioxide $\left(\mathrm{CO}_{2}\right)$ from industrial sources as stable solid carbonates. An experimental investigation is conceived, whereby students test the effect of two process parameters $\left(\mathrm{CO}_{2}\right.$ pressure and mixing rate) on the extent of carbonation reaction. The carbonation reaction has been performed using a mineral called wollastonite $\left(\mathrm{CaSiO}_{3}\right)$. The experimental study and laboratory report cover principles of reaction kinetics and mass transfer, while illustrating the steps to develop and investigate a green process technology. The results from the experimental investigation, which is carried out by multiple teams of students, are then pooled and used to guide a subsequent design project. Students would conceive a flowsheet, size equipment, and estimate the energy demand and net $\mathrm{CO}_{2}$ sequestration efficiency of a full-scale implementation of the mineral carbonation technology. This educational investigation aims to help undergraduate students to acquire deeper experiential learning and greater awareness of future green technologies by applying fundamental engineering principles into an engaging experimental and design exercise.
\end{abstract}

Keywords: mineral carbonation; reaction kinetics; mass transfer; wollastonite; experimental investigation; process design; green chemical engineering; climate change mitigation

\section{Introduction}

Sustainability planning requires fundamental investment on education, moving towards training students in innovative environmental technologies that they should be aware of to develop cleaner production processes, and to be capable of participating in and promoting continuous improvements in the economy, environment, and society [1]. Green Chemistry is a scientific field created as a consequence of pollution prevention initiatives, and it is based on principles that reduce waste production, promote efficient use of resources, and decrease demands on energy while improving environmental sustainability [2]. The implementation of Green Chemistry has provided many opportunities for professors to design innovative and environmentally friendly experiments as well as developing their secondary courses, to educate and guide the next generation of chemistry professionals [3,4]. This common practice of incorporating Green Chemistry into curricular activities and the design of novel experiments assists students in developing comprehensive perspectives skills, moving them beyond simple yields calculations to environmentally sustainable practices [5].

In the study of applied chemistry and chemical engineering, practical work has unquestionable importance, given its relevance for professional job preparation, and can certainly provide unique opportunities to develop investigative skills [6,7]. However, most laboratory experiments performed by 
students in undergraduate programs (at universities, polytechnic institutes, and colleges) are based on well-established reactions and physical phenomena that were originally developed based on industrial practices that are now decades old. The lack of coherent learning objectives and the observed student isolation in laboratories could cause to disengage them from the learning process [8]. Although faculty members have decreased student isolation over the years, assigning students to work in collaborative teams is more effective [8].

In the authors' experiences as teachers and students, it is noticed that many laboratory experiments and design projects used in coursework (apart from capstone projects) are disconnected from one another, and students often perform identical experiments to other students or are not allowed or encouraged to share data. This results in students not having the opportunity to further utilize and build on the experimental data they produce, and the experimental dataset the class produces. Time (i.e., experiment duration), the high cost of laboratory equipment, and, in some cases, excessive procedural complexity, represent constraints to explore innovative ideas and collaborative and progressive work in the educational setting.

It is the authors' conception that students are more likely to feel engaged in this experiential learning when they can see the importance of what they are required to do, be it a skill that they think they will use in the future, or knowledge they will gain about real-world issues and solutions for them. Martínez and Campos [9] discuss how the level of accomplishment between students is directly linked to the commitment level they demonstrate, which is reflected by how they address their inquiry questions and the quality of the concept studied before starting the experimental activity, also improving the scientific thinking ability.

There are plenty of Green Chemistry and sustainable technology topics that are or have recently started finding their way into real-world implementation [10,11]. Carbon sequestration is one of the main strategies available for climate change mitigation via reduction of greenhouse gas emissions, and among the many options for carbon sequestration, mineral carbonation is one that has a potential to sequester significant amounts of carbon dioxide $\left(\mathrm{CO}_{2}\right)$ [12-16]. This technology has a high potential to capture and safely store massive amounts of $\mathrm{CO}_{2}$ to mitigate the increase of the atmospheric concentration, which has risen from around $280 \mathrm{ppm}$, at the beginning of the industrial revolution, to over 410 ppm, according to National Oceanic and Atmospheric Administration [17] and The International Panel for Climate Change [18].

Mineral carbonation is the reaction between $\mathrm{CO}_{2}$ and alkaline minerals (i.e., those that contain alkaline earth elements) that produce geologically stable carbonate minerals, such as calcite $\left(\mathrm{CaCO}_{3}\right)$, dolomite $\left(\mathrm{CaMg}\left(\mathrm{CO}_{3}\right)_{2}\right)$, magnesite $\left(\mathrm{MgCO}_{3}\right)$, and, in some cases, even siderite $\left(\mathrm{FeCO}_{3}\right)[12,13]$. Alkaline minerals come in different varieties: they include mafic and ultramafic igneous rocks, such as basalt, wollastonite, olivine, and serpentine, but also solid residues from the steelmaking industry, waste incineration, and building demolition, such as slags, ashes, or asbestos [19-22].

Mineral carbonation is a challenging theme to demonstrate to students because the chemical reaction at ambient conditions, also referred by geologists as "weathering", proceeds extremely slowly over a geological time scale, consequently demanding accelerated process conditions for experimental analysis. This also relates to the need for accelerated carbonation for industrial implementation. To mitigate anthropogenic $\mathrm{CO}_{2}$ emissions, the reaction must be sped up to the point where $\mathrm{CO}_{2}$ can be fixated at the same rate that it is generated in the burning of fossil fuels (or calcination of limestone), to create an economically and environmentally sustainable process. Still, after many years of research and development, mineral carbonation is beginning to be implemented at the industrial scale. Examples of companies around the world using mineral carbonation, primarily to produce building materials, include CarbonCure Technologies in Canada [23]; Carbon8 Systems in the United Kingdom [24]; Mineral Carbonation International in Australia [25]; Solidia Technologies in the United States [26]. 


\section{Aims and Objectives}

Given its strong link to concepts of sustainability and Green Chemistry and process requirements that apply principles of reaction kinetics, transport phenomena, and materials characterization, the present work aimed to find a way for accelerated mineral carbonation to earn a place in chemical engineering curricula. To this end, an experimental investigation laboratory procedure and a design project outline were conceived and applied (for the first time in Summer 2017) in the Chemical Engineering Technologist Advanced Diploma program at the Sheridan College Institute of Technology and Advanced Learning. As a way to further engage students in this learning experience, the process conditions for the laboratory work were varied between groups of students, and the experimental data obtained were pooled to be used by every group for the subsequent design exercise. This was meant to give students motivation to generate accurate data that they knew would be useful for the entire class and, at the same time, provide students with the opportunity to use data generated by colleagues, much in the same way the design work is done in the industry.

The experimental investigation and design project, herein presented, are suitable for implementation in upper-year undergraduate (Bachelor or Advanced Diploma) engineering and engineering technology programs, and also for graduate courses at the Master's level. For example, in 3rd or 4th year of University undergraduate degrees and 3rd year of College diplomas in North America, or the 3rd, 4th, or 5th years of higher education programs in countries that follow the Bologna Accord (i.e., Europe).

The ultimate objective was to better train chemical engineering students given their future careers. Graduates with experience in mineral carbonation investigation and design would potentially be better trained to develop engineering solutions that take into account sustainability criteria. Also, having gone through a memorable undergraduate exercise in mineral carbonation investigation and design would potentially reinforce learned concepts of chemical engineering fundamentals, and make it more likely that graduate would recall those fundamental concepts in their future careers.

Section 2, 3, 4, and 5.1 of this concept paper, along with the two Supplementary Materials files, present the information that was provided to students in their laboratory investigation procedure and design project outline. Section 2 gives the background of the mineral carbonation process, which helps students to become familiar with the subject and to see links with fundamental concepts they learned in the classroom, including in previous classes. Section 3 and Supplementary_Material_1 provide students with the knowledge and step-by-step instructions on how to perform the experimental investigation. Section 4 details the calculations required to process the experimental data, and additional questions students must answer related to the investigation and the subject matter to interpret and explain the achieved results. Section 5.1 and Supplementary_Material_2 provide students guidance on the design project (to be implemented in a future course), both in terms of requirements and a general procedure (allowing student some freedom on how they set-up and analyze their design). In Section 5, the experience with running the experimental investigation at Sheridan College is discussed, and, in Section 6, conclusions are offered.

\section{Experimental Investigation Part A: Background of Mineral Carbonation}

Fundamentally, mineral carbonation occurs when carbon dioxide reacts with metal oxides or natural alkaline silicates (containing calcium or magnesium). The corresponding carbonate is formed, releasing heat, according to the following chemical reaction (Equation (1)), where M represents a divalent metal [27]:

$$
\mathrm{MO}+\mathrm{CO}_{2} \rightarrow \mathrm{MCO}_{3}+\text { heat }
$$

Silicates rocks are available in vast amounts worldwide and represent the ideal material for mineral carbonation. Often used minerals include olivine $\left((\mathrm{Mg}, \mathrm{Fe}) \mathrm{SiO}_{4}\right)$ [28], forsterite $\left(\mathrm{Mg}_{2} \mathrm{SiO}_{4}\right)$ [29], serpentine $\left(\mathrm{Mg}_{3} \mathrm{Si}_{2} \mathrm{O}_{5}(\mathrm{OH})_{4}\right)$ [30], and wollastonite $\left(\mathrm{CaSiO}_{3}\right)$ [31]. Several industrial residues (such as combustion/incineration ashes, mining tailings, and metallurgical slags) also contain alkaline silicates, 
often more complex, such as chrysotile $\left(\mathrm{Mg}_{3}\left(\mathrm{Si}_{2} \mathrm{O}_{5}\right)(\mathrm{OH})_{4}\right)$ [32] and brownmillerite $\left(\mathrm{Ca}_{2}(\mathrm{Al}, \mathrm{Fe})_{2} \mathrm{O}_{5}\right)$ [33] and, at times, amorphous (lacking crystal structure). Calcium-based minerals are usually more reactive than magnesium-based minerals, basically, because the $\mathrm{Ca}$ atom is larger than the $\mathrm{Mg}$ atom, and consequently the valence electron is less tightly bound to the $\mathrm{Ca}$ atom. Wollastonite is one of the most reactive natural minerals to carbonation, but it is also less abundant than other less reactive minerals [34]. When milled, its particles normally have an acicular (needle-like) morphology of high aspect ratio (i.e., much longer in one dimension and much narrower in the others) [35] (Figure 1). Stoichiometrically, $1.16 \mathrm{t}$ of wollastonite can sequester $1 \mathrm{t}$ of $\mathrm{CO}_{2}$.

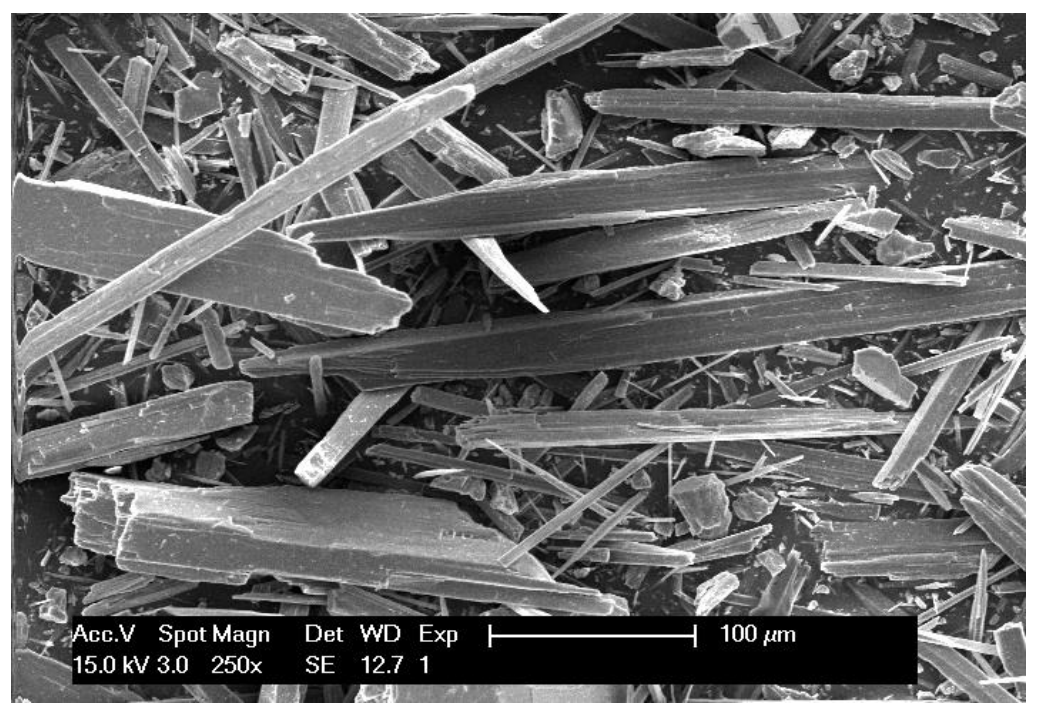

Figure 1. Electron Microscopy image of acicular (needle-like) wollastonite particles (CasifluxßF 125 (NYCO Minerals, Willsboro, NY, USA), $\mathrm{D}_{50}=57 \mu \mathrm{m}$ ) used in the present experiments.

According to the dissolution reaction of carbon dioxide (Equation (2)) and the principle of le Chatelier-Braun, the carbonate and bicarbonate anion and hydronium cation concentrations increase as the $\mathrm{CO}_{2}$ partial pressure rises. Thus, the diffusion rate, silicate dissolution rate (Equation (3)), and the rate of calcium carbonate precipitation (Equation (4)) also increase, up to a point, where the $\mathrm{pH}$ becomes too low and the carbonate begins to dissolve again (Equation (5)). This is not so problematic, as gas compression is also costly, so an optimal level of compression would exist that maximizes the rate of $\mathrm{CO}_{2}$ sequestration while maintaining reasonable cost. It is important to note that because several chemical reactions occur simultaneously in the system, it could happen that a change in processing conditions would improve one reaction, but be detrimental to the overall reaction (Equation (6)) rate.

$$
\begin{gathered}
\mathrm{CO}_{2(\mathrm{~g})}+\mathrm{H}_{2} \mathrm{O}_{(\mathrm{l})} \leftrightharpoons \mathrm{H}_{2} \mathrm{CO}_{3(\mathrm{aq})} \leftrightharpoons \mathrm{HCO}_{3}{ }^{-}+\mathrm{H}^{+} \leftrightharpoons \mathrm{CO}_{3}{ }^{2-}+2 \mathrm{H}^{+} \\
\mathrm{CaSiO}_{3(\mathrm{~s})}+2 \mathrm{H}^{+} \rightarrow \mathrm{Ca}^{2+}+\mathrm{SiO}_{2(\mathrm{~s})}+\mathrm{H}_{2} \mathrm{O}_{(\mathrm{l})} \\
\mathrm{CO}_{3}^{2-}+\mathrm{Ca}^{2+} \leftrightharpoons \mathrm{CaCO}_{3(\mathrm{~s})} \\
\mathrm{CaCO}_{3(\mathrm{~s})}+2 \mathrm{H}^{+} \leftrightharpoons \mathrm{Ca}^{2+}+\mathrm{H}_{2} \mathrm{O}_{(\mathrm{l})}+\mathrm{CO}_{2(\mathrm{~g})} \\
\mathrm{CaSiO}_{3(\mathrm{~s})}+\mathrm{CO}_{2(\mathrm{~g})} \rightarrow \mathrm{CaCO}_{3(\mathrm{~s})}+\mathrm{SiO}_{2(\mathrm{~s})}
\end{gathered}
$$

The more acidic the bulk solution is, more free protons are available to attack the mineral and leach the $\mathrm{Ca}$ from its matrix. Looking at the reactions above, this also becomes clear using the Le Chatelier-Braun principle. The lowering of the $\mathrm{pH}$ could be achieved by increasing the $\mathrm{CO}_{2}$ pressure or by adding external acids. The carbonate would eventually have more trouble to precipitate; however, it dissolves when the $\mathrm{pH}$ is too low. This is not usually a problem when solely carbonic acid is the acidic 
species since the dissolution of the silicate (Equation (3)) consumes the acid formed (Equation (2)). Daval et al. [36] reported that, with $\mathrm{pCO}_{2}=250$ bar and $\mathrm{T}=90^{\circ} \mathrm{C}$, the equilibrium $\mathrm{pH}$ of an aqueous solution of $\mathrm{CO}_{2}$ was 3.07 , but increased to 4.61 in the presence of carbonating wollastonite.

Because the mineral carbonation reaction (illustrated in Figure 2 for steelmaking slag) proceeds by the diffusion of carbonate anions into a solid mineral matrix, it is imperative that a high surface-to-volume ratio is created by first crushing the mined ore and subsequently milling the particles to a specified particle size [37-39]. To further improve the overall reaction rate, aside from reducing the particle size and increasing the $\mathrm{CO}_{2}$ pressure, another strategy is to introduce chemical additives to the aqueous phase. These additives could help to increase the $\mathrm{CO}_{2}$ solubility and carbonic acid dissociation (by shifting Equation (2) equilibrium), increase the mineral dissolution rate (by shifting Equation (3) equilibrium), or reduce the acidification (to avoid the reaction of Equation (5)). Chemicals, such as $\mathrm{NaOH}, \mathrm{NaHCO}_{3}, \mathrm{NH}_{4} \mathrm{Cl}$, and acetic acid, have been used for these purposes [40]. Additives do pose challenges; however, they can be costly and need to be separated and regenerated to be recycled.
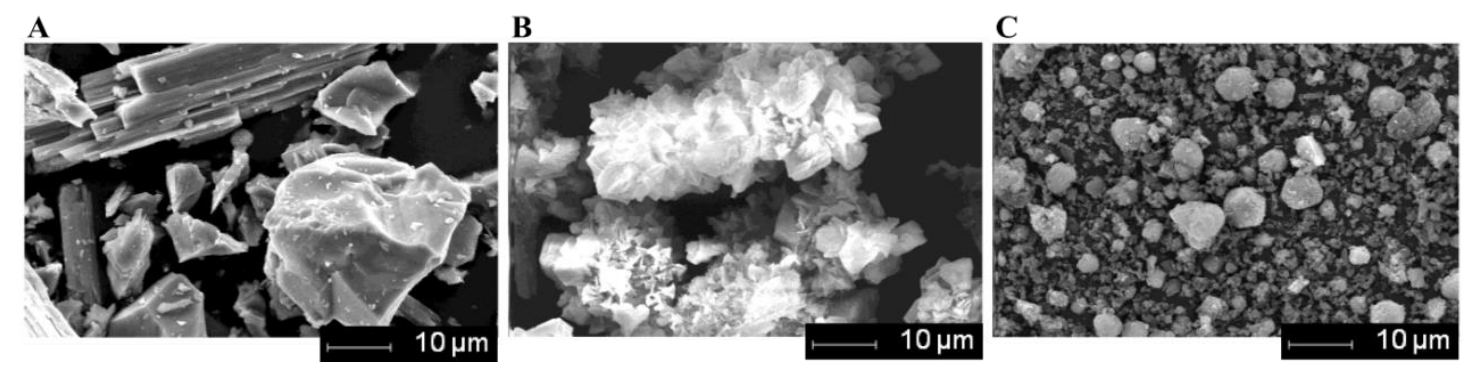

Figure 2. Comparison of particle morphology of original (A); stirred carbonated (B); sonicated carbonated (C) Continuous Casting slag powders [41] (CC BY).

\subsection{Reaction Rate and Kinetics}

The reaction rate ( $r$ ) of wollastonite dissolution in acidic medium is reported to obey the following expression (Equation (7)) [42]:

$$
\ln \left(\mathrm{r}_{\min }\right)=\ln (\mathrm{A})-\mathrm{E}_{\mathrm{A}} /(\mathrm{R} \times \mathrm{T})
$$

where $r_{\min }$ is the mineral dissolution rate $\left(\mathrm{mol} /\left(\mathrm{m}^{2} \cdot \mathrm{s}\right)\right)$, A is the pre-exponential empirical factor $\left((1.8 \pm 0.9) \cdot 103 \mathrm{~mol} /\left(\mathrm{m}^{2} \cdot \mathrm{s}\right)\right.$ in the case of wollastonite dissolution in acetic acid [42]), $\mathrm{E}_{\mathrm{A}}$ is the apparent activation energy of dissolution (47 $\pm 1 \mathrm{~kJ} / \mathrm{mol}[42]), \mathrm{R}$ is the universal gas constant $(\mathrm{kJ} /(\mathrm{mol} \cdot \mathrm{K}))$, and $\mathrm{T}$ is the temperature $(\mathrm{K})$.

Since mineral dissolution is seen as the rate-limiting step in mineral carbonation $\left(\mathrm{CO}_{2}\right.$ dissolution and carbonate precipitation are comparatively fast [36]), the rate of carbonation $\left(\mathrm{R}_{\text {carb }}(\mathrm{mol} / \mathrm{s})\right)$ can be estimated from the rate of dissolution and the available mineral surface area $\left(A_{\min ,(t)}\left(\mathrm{m}^{2}\right)\right)$ by the following expression (Equation (8)):

$$
\mathrm{R}_{\text {carb }}=\mathrm{r}_{\min } \times \mathrm{A}_{\min ,(\mathrm{t})}
$$

The available mineral surface area is a function of time ( $t$ ) since it will gradually reduce as carbonation proceeds (i.e., the reaction front shrinks from the surface of the particle towards its core, as illustrated in Figure 3). It can be approximated by the product of the initial specific surface area (SSA $\left.\left(\mathrm{m}^{2} / \mathrm{g}\right)\right)$ of the mineral, the fractional extent of carbonation conversion of the mineral at the reaction time $\left(\xi_{(t)}\right)$, and the initial mass of wollastonite being carbonated $\left(\mathrm{m}_{\mathrm{wo}, \text { init }}(\mathrm{g})\right)$ (Equation $\left.(9)\right)$ :

$$
\mathrm{A}_{\min ,(\mathrm{t})}=\mathrm{SSA} \times\left(1-\xi_{(\mathrm{t})}\right) \times \mathrm{m}_{\mathrm{wo}, \text { init }}
$$




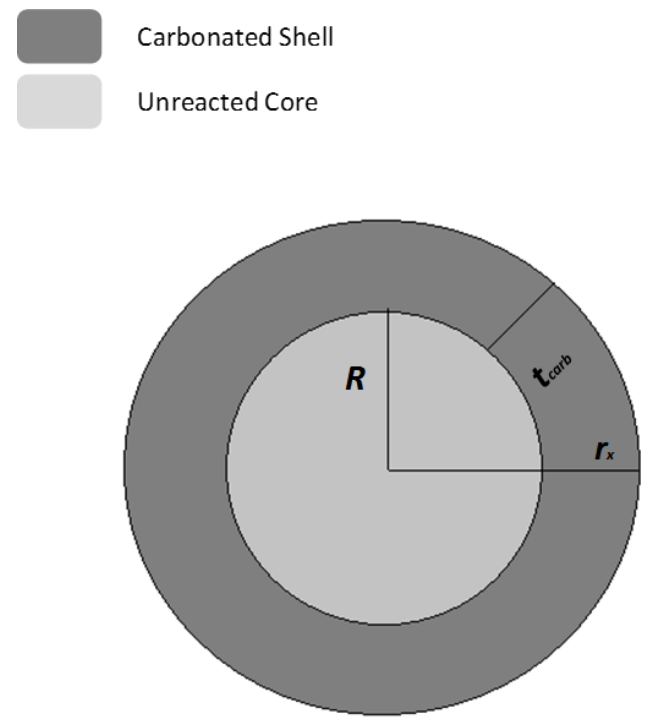

Figure 3. Illustration of the partially carbonated mineral particle, according to shrinking core model [43], where $r_{x}$ is the original particle radius, $R$ is the radius of the unreacted core of the particle, and $t_{\text {carb }}$ is the thickness of the carbonated shell. Re-used with permission from John Wiley and Sons (4592190232399).

The fractional extent of carbonation conversion of the mineral at the reaction time is the ratio of the number of mols of calcium that have become $\mathrm{CaCO}_{3}$ at the reaction time $\left(\mathrm{n}_{\mathrm{CaCO},(\mathrm{t})}\right)$ over the total number of mols of calcium in the wollastonite being carbonated ( $\left.\mathrm{n}_{\mathrm{wo}, \mathrm{init}}\right)$, according to Equation (10):

$$
\xi_{(\mathrm{t})}=\mathrm{n}_{\mathrm{CaCO},(\mathrm{t})} / \mathrm{n}_{\mathrm{wo}, \text { init }}
$$

\section{Reacted Particle Morphology}

When wollastonite carbonates, two solid products form: calcium carbonate (typically as the calcite polymorph) and amorphous silica. The behavior of these two product phases, in terms of where they end up, differs. Daval et al. [44] observed that at the micrometer-scale, wollastonite replacement occurred pseudomorphically: the acicular shape of the wollastonite grains was preserved, as the silica product remained in the place where wollastonite originally existed. Thus, in each particle, the silica layer remains adjacent to the unaltered wollastonite core. Daval et al. [44] postulated that the pseudomorphic texture implied an intrinsic silica precipitation rate much greater than the dissolution reaction. As a result, silica product that detaches from the reacting wollastonite interface is immediately reprecipitated by the silica layer-wollastonite core interfacial region, thus preserving the original particle morphology.

In cases where the wollastonite particle contains secondary phases (such as diopside $\left(\mathrm{MgCaSi}_{2} \mathrm{O}_{6}\right)$, this phase may further slow the carbonation reaction, especially if it is inert to carbonation, or has much slower carbonation kinetics (which tends to be true for magnesium-based silicates). Depending on the degree of mixing of wollastonite with diopside, the diopside may appear as separate grains upon milling, or as micro-crystals within the wollastonite matrix [34]. In the former case, its effect on carbonation kinetics of wollastonite should be minimal, but in the latter, where it would accumulate in the calcium-depleted layer surrounding the unreacted core, it could have a significant effect in hindering ion diffusion.

\subsection{Effects of Process Parameters}

\subsubsection{Temperature and $\mathrm{CO}_{2}$ Pressure}

Temperature is an important process parameter that can be adjusted to improve the overall rate of reaction. There are two phenomena that are dependent on temperature: (i) the solubility of 
carbon dioxide, which decreases with higher temperatures, and this results in a higher $\mathrm{pH}$, which is detrimental for the mineral dissolution rate; (ii) the dissolution rate of silicate minerals, which, on the other hand, increases with higher temperatures.

Because of the opposite direction of these two concurrent effects, an optimum temperature exists for the carbonation of each mineral. In the case of wollastonite, it has been reported that the process should be conducted below $200{ }^{\circ} \mathrm{C}$ [45], depending on the $\mathrm{CO}_{2}$ pressure [46]. The higher the pressure, the higher the optimum temperatures would be.

\subsubsection{Agitation}

$\mathrm{CO}_{2}$ in the gas phase is transported across a gas-liquid interface, as it dissolves from the headspace into the slurry below. The mechanism of calcium ions reaction is less clear; there are two scenarios. In one scenario, calcium ions move as ions from the surface of the solid particles to the liquid phase and then react with carbonate ions to precipitate as calcium carbonate crystals. Another scenario is that calcium ions precipitate at the surface of particles, where they meet the carbonate coming from the liquid phase, and later calcium carbonate crystals are dislodged from the surface due to agitation [47].

Mass transfer can be improved in the liquid phase, to aid in $\mathrm{CO}_{2}$ dissolution and calcium carbonate crystallization, by agitation. Agitation improves the convective mass transfer mechanism, which is more important than diffusion in the liquid phase [48]. Convection enhances mass transfer across interfaces by reducing the thickness of boundary layers (the region near an interface where ions accumulate), thus increasing the driving force: the concentration difference. Ideally, for ions to leach out from a solid surface, the concentration of that ion in the liquid phase, at the interface, should be as close to zero as possible, which is possible in a system where the ion later precipitates in the liquid [49].

\subsection{Determination of the Reaction Extent}

As wollastonite (and any other calcium- or magnesium-rich mineral) reacts with $\mathrm{CO}_{2}$, solid carbonates form. These carbonates can be Ca-carbonates, $\mathrm{Mg}$-carbonates, and a variety of Ca-Mg-carbonates [50]. The most common Ca-carbonate is $\mathrm{CaCO}_{3}$, referred to as calcium carbonate, which forms under a range of process conditions. Calcium carbonate is particularly special as it can have three polymorphs: calcite, aragonite, and vaterite. All have the same chemical composition, but different crystal structures (and consequently particle morphologies). A less common Ca-carbonate would be monohydrocalcite $\left(\mathrm{CaCO}_{3} \cdot \mathrm{H}_{2} \mathrm{O}\right)$. When magnesium is also present in appreciable quantities in the mineral ore, calcium can co-precipitate with magnesium to form $\mathrm{Mg}$-rich carbonates, such as huntite $\left(\mathrm{Mg}_{3} \mathrm{Ca}\left(\mathrm{CO}_{3}\right)_{4}\right)$, and Ca-rich carbonates, such as magnesian-calcite $\left(\mathrm{Mg}_{0-0.15} \mathrm{Ca}_{0.85-1} \mathrm{CO}_{3}\right)$. Finally, when $\mathrm{Mg}$-carbonates are the predominant carbonation products, possible forms include anhydrous $\mathrm{MgCO}_{3}$ (magnesite), its hydrated form as nesquehonite $\left(\mathrm{MgCO}_{3} \cdot 3 \mathrm{H}_{2} \mathrm{O}\right)$, among others.

For $\mathrm{CO}_{2}$ sequestration by wollastonite, and for kinetics and mass transfer determinations, the principal need is to determine the total amount of $\mathrm{CO}_{2}$ bound in mineral form. Also, given the chemical composition of wollastonite ore, it can be assumed that $\mathrm{CaCO}_{3}$ is the predominant carbonate product. Thus, how does one determine the amount of $\mathrm{CaCO}_{3}$ in a solid sample? Four common approaches are briefly described next. In addition to these, other more specialized techniques exist that can identify and/or quantify the presence of carbonates. Some are standalone techniques, and others are used in combination with other techniques; examples include: Energy Dispersive Spectrometry (can detect elemental carbon and its spatial association with other elements), Fourier Transform Infrared (can detect chemical bonding of carbonates in solid phase, and $\mathrm{CO}_{2}$ in gas phase), Mass Spectrometry (can detect $\mathrm{CO}_{2}$ in gas phase), Total Carbon Analyzers (can determine total carbon, total organic carbon, and total inorganic carbon contents), among others.

\subsubsection{X-ray Diffraction (XRD)}

The most direct method of detection is by X-ray Diffraction (XRD) analysis. This is a technique that determines the distance between atoms in a crystal, thus allowing precise determination of the 
types of minerals present in a sample. Using the Rietveld Refinement Method and internal standards, it is possible to estimate with reasonable accuracy and precision $( \pm 2-3 \mathrm{wt} \%)$ the mass fractions of different crystalline minerals in the sample, as well as the total mass fraction of amorphous content [51]. Of the four methods described here, this is the only one that could differentiate calcite from aragonite (polymorphs of $\mathrm{CaCO}_{3}$ ) [52]. An example of an X-ray diffractogram showing this distinction is seen in Figure 4.

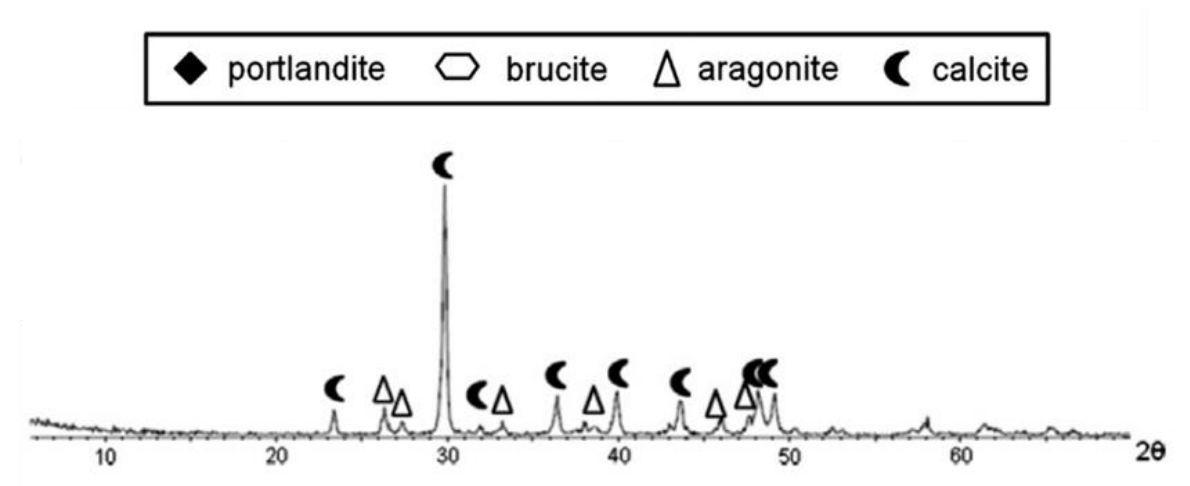

Figure 4. X-ray diffractogram of carbonated calcium hydroxide, with major crystalline phases indicated [51]; re-used with permission from Elsevier (4592190838155).

\subsubsection{Thermogravimetric Analysis (TGA)}

Another instrumental method to detect carbonate content of solid samples is Thermogravimetric Analysis (TGA). This method relies on the thermal decomposition of carbonates when samples are heated to elevated temperatures, which causes the solid sample to lose mass. In theory, different carbonates will demonstrate different decomposition temperatures. However, the method is not able to precisely discern carbonates with close decomposition temperature [53]. Most commonly, the mass losses are divided into two stages: between approximately $300^{\circ} \mathrm{C}$ and $500^{\circ} \mathrm{C}, \mathrm{MgCO}_{3}$ decomposes, and between $500{ }^{\circ} \mathrm{C}$ and $800{ }^{\circ} \mathrm{C}, \mathrm{CaCO}_{3}$ decomposes [54]. Hydrated and hydroxylated carbonates will experience some mass loss at lower temperatures, as a result of water release, but the carbonate groups should still decompose in the aforementioned ranges. To avoid overestimation of carbonate content, evolved gas analysis can be used to discern $\mathrm{CO}_{2}$ from other volatiles [55]. Figure 5 shows examples of TGA curves for $\mathrm{CaCO}_{3}, \mathrm{MgCO}_{3}$, and $\mathrm{Ca}(\mathrm{OH})_{2}$.

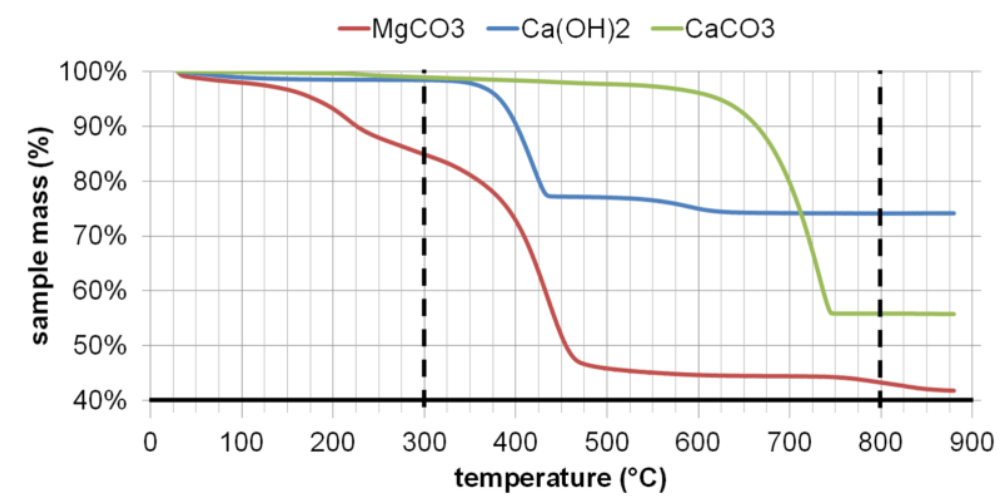

Figure 5. Thermal gravimetric analysis of analytical grade solids [54]; re-used with permission from Elsevier (4592190653818).

\subsubsection{Calcimetry}

The third method also relies on the decomposition of carbonates, but, rather than using heat, the method uses acidification. This method is called calcimetry or gasometric analysis and is performed 
using a calcimeter. The working principle is based on Equation (5); when a carbonate is exposed to a sufficiently strong acid (typically $\mathrm{HCl}$ or $\mathrm{HNO}_{3}$ ), $\mathrm{CO}_{2}$ gas is released. The calcimeter measures the volume (or pressure) of released gas, which is used to estimate the carbonate content of the sample. Figure 6 illustrates the use of this method, based on pressure, for determination of $\mathrm{MgCO}_{3}$ content. An advantage of this method over the TGA method is that only $\mathrm{CO}_{2}$ is released by acidification, so it avoids possible overlap with vapor release (which is more problematic for samples containing Mg-carbonates). Some disadvantages include lower accuracy, greater detection limit, and the inability to discern between different carbonates, including Mg- and Ca-carbonates [55,56].

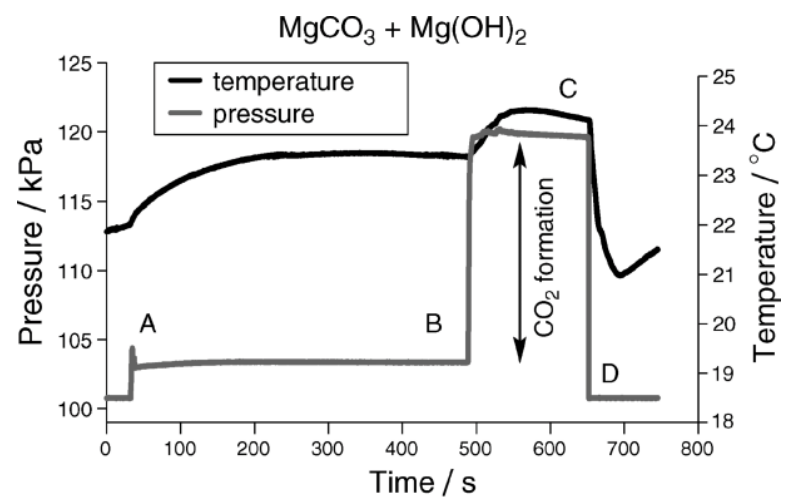

Figure 6. Temperature and pressure profiles of gasometric carbonate analysis experiment, where the letters denote container sealed (A), sample and $\mathrm{HCl}$ mixed (B), maximum pressure (C), and container opened (D) [57]; reprinted with permission from Fagerlund et al. [57], copyright 2010 American Chemical Society.

\subsubsection{Acid-Base Titration}

The last method herein described is the acid-base titration. This method is similar to the previously described gasometric analysis, in that acid is used to dissolve the carbonates. However, detection is done by chemical $(\mathrm{pH})$ rather than physical (volume or pressure) means. The method consists of two steps [58,59]. In the first step, the sample is gradually acidified, typically using $\mathrm{HCl}$, while the $\mathrm{pH}$ is monitored. The $\mathrm{pH}$ will indicate when the carbonates have been fully consumed (Equation (11)). Before they are consumed, carbonates will buffer the $\mathrm{pH}$, which will remain relatively constant. When the carbonates fully dissolve, a $\mathrm{pH}$ step occurs, where the $\mathrm{pH}$ will decrease until another component in the mineral becomes the $\mathrm{pH}$-controlling mineral. An example is shown in Figure 7 for the acidification of red mud (a by-product of aluminum production). In red mud, an aluminate controls the $\mathrm{pH}$ of the material at first, followed by a silicate at lower $\mathrm{pH}$, and followed by calcite at an even lower $\mathrm{pH}$ [60]. As can be seen, the $\mathrm{pH}$ of calcite is near nine, and when it is fully consumed by the acid, the $\mathrm{pH}$ drops to below six.

$$
\begin{gathered}
\mathrm{CaCO}_{3(\mathrm{~s})}+2 \mathrm{HCl} \rightarrow \mathrm{CaCl}_{2(\mathrm{aq})}+\mathrm{H}_{2} \mathrm{O}_{(\mathrm{l})}+\mathrm{CO}_{2(\mathrm{~g})} \uparrow \\
\mathrm{HCl}_{(\mathrm{aq})}+\mathrm{NaOH}_{(\mathrm{aq})} \rightarrow \mathrm{NaCl}_{(\mathrm{aq})}+\mathrm{H}_{2} \mathrm{O}_{(\mathrm{l})}
\end{gathered}
$$

At this point in the acid-base titration method, phenolphthalein is added, and the solution is back-titrated with $\mathrm{NaOH}$ (Equation (12)), until the phenolphthalein endpoint (pink color). The difference between the amount of acid added and the amount of excess acid neutralized by sodium hydroxide is the amount of acid that is consumed in dissolving the minerals. Back-titration is used because the acid titration reaction cannot be used directly to titrate the $\mathrm{CaCO}_{3}$, as it is very slow when the reaction is close to the endpoint. Heating the solution can help degas the release $\mathrm{CO}_{2}$, and thus sharpen the endpoint [61]. Disadvantages of this method are similar to those for gasometric analysis. 


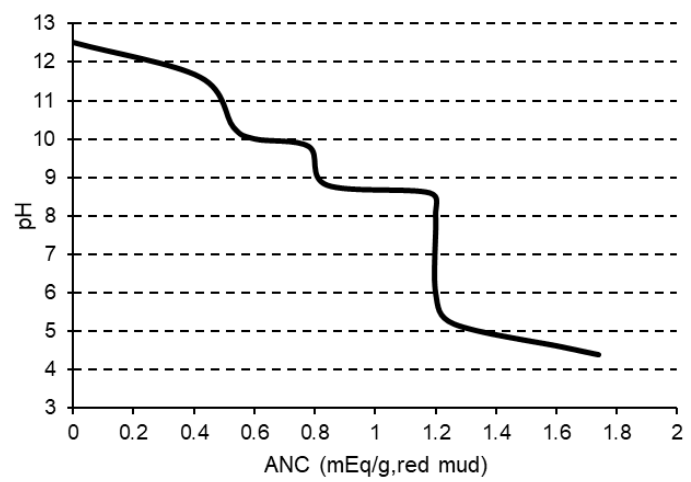

Figure 7. Hydrochloric acid titration curve of red mud, re-plotted using data as simulated by Khaitan et al. [62].

\section{Experimental Investigation Part B: Materials and Methods}

In the following sub-sections, the materials and equipment utilized for the accelerated mineral carbonation experimental investigation developed and performed at Sheridan College are described. Several other types of alkaline minerals and different types of pressurized reactors can replace those specified below, though process conditions may need to be altered from those described here.

\subsection{Mineral}

The wollastonite material used in this lab was obtained from NYCO Minerals (Willsboro, NY, USA). The chemical composition of the material was determined by X-ray Fluorescence (XRF) and is presented in Table 1. It consists mainly of calcium and silicon oxides, consistent with the chemical formula of wollastonite, $\mathrm{CaSiO}_{3}$. The Ca:Si molar ratio is 1.18, slightly higher than that of pure wollastonite mineral, which is 1 . The maximum $\mathrm{CO}_{2}$ sequestration capacity, based on the calcium and magnesium contents (i.e., if they all become carbonated), would be 409.9 grams of $\mathrm{CO}_{2}$ per kilogram of wollastonite material. (i.e., if all calcium is carbonated). The resulting product would contain $29.1 \mathrm{wt}$. $\% \mathrm{CO}_{2}$. Additional characterization data (mineralogical and particle size analyses) are presented in the Appendix.

Table 1. Chemical composition of wollastonite material, determined by XRF (X-ray Fluorescence) and expressed as oxides.

\begin{tabular}{cc}
\hline Oxide & Wt $\%$ \\
\hline $\mathrm{CaO}$ & $51.2 \pm 0.6$ \\
$\mathrm{SiO}_{2}$ & $46.4 \pm 0.3$ \\
$\mathrm{Al}_{2} \mathrm{O}_{3}$ & $0.79 \pm 0.04$ \\
$\mathrm{MgO}$ & $0.70 \pm 0.05$ \\
$\mathrm{Fe}_{2} \mathrm{O}_{3}$ & $0.52 \pm 0.06$ \\
$\mathrm{~K}_{2} \mathrm{O}$ & $0.14 \pm 0.02$ \\
\hline
\end{tabular}

\subsection{Pressurized Reactor}

The reactor used for carbonation was from Parr Instrument Company (Moline, IL, USA), model 4525 , which is a continuously stirred, pressurized, and jacket-heated tank reactor. The nominal reactor volume is $1000 \mathrm{~mL}$, and the material of construction of the head, cylinder, and internal wetted parts is Alloy C-276 (commonly referred to as Hastelloy). The reactor sits on a bench-top stand, and is removable, including the head. Figure 8 shows the reactor, with major components indicated, and additional details are illustrated in Supplementary_Material_1. This reactor is capable of withstanding temperatures up to $300^{\circ} \mathrm{C}$ (using PTFE flat gasket) and pressures up to $200 \mathrm{bar}$ (2900 psi). The carbon dioxide compressed gas cylinder is supplied by Praxair (Guildford, United Kingdom) (CAS 
12-38-9) and is of industrial grade (min. 99.5\% purity). Heating is provided by an aluminum-block electrically heated jacket, energized, and regulated by a Parr 4848 proportional-integral-derivative (PID) temperature control unit. Cooling is done by water circulating through the heating jacket, controlled manually via a needle valve. The pressure is provided by the connected gas cylinder, and autogenously by vaporization of water content. Stirring is enabled by a mechanical shaft and impeller, externally coupled to a variable speed $1 / 4 \mathrm{hp}$ motor and an rpm controller. The stirring shaft is fitted with dual Rushton turbine impellers, and a baffle is present to ensure adequate mixing. The reactor's bottom drain was fitted with a simple plug (replacing the original valve) to allow drainage of liquid and slurry from the reactor.

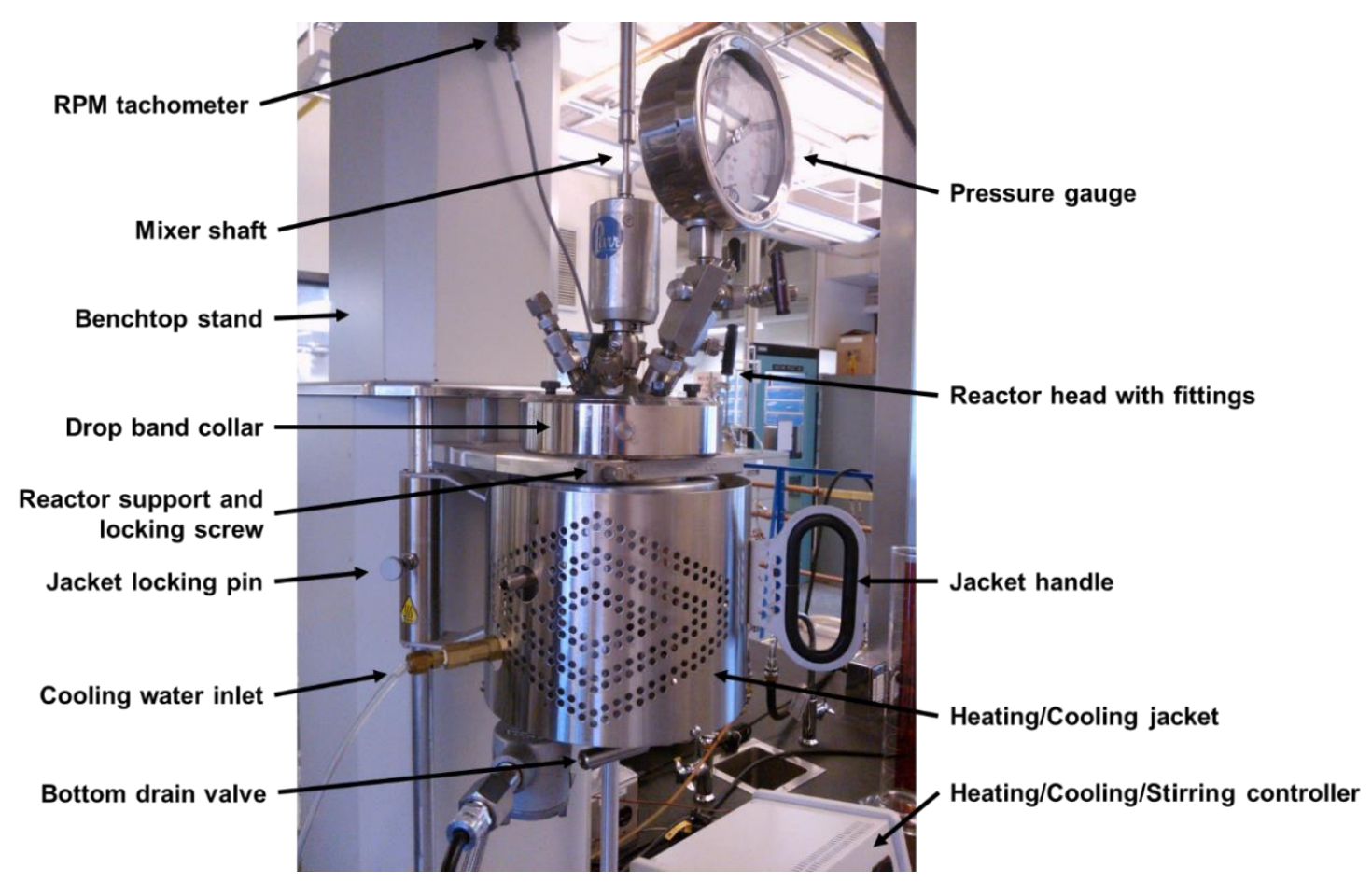

Figure 8. Parr 4525 pressurized reactor, with main components indicated.

\subsection{Process Parameters}

It is possible to vary several process parameters to study the carbonation of wollastonite in the continuously stirred pressurized reactor. For this lab, which is the study of reaction kinetics and mass transfer, and based on the number of experiments planned, some parameters were kept constant. These include:

- The volume of water in the reactor: the stirrer blades were fixed to a certain height, so changing the amount of water would imply that mixing would become difficult if the water level became too low. Thus, a value that is well suited for the $1 \mathrm{~L}$ reactor was used: $800 \mathrm{~mL} \mathrm{H}_{2} \mathrm{O}$.

- Mass of solids in the reactor: decreasing the liquid-to-solid (L/S) mass ratio could help promote particle-particle interaction, which might aid in carbonation conversion by eroding the silica layer, but, at too low values, mixing becomes problematic. To ensure good mixing, a relatively high L/S ratio was used: 20 (i.e., $40 \mathrm{~g}$ wollastonite material).

- Residence time: the higher the residence time, the higher the carbonation conversion [45]. However, to study the effect of process parameters on reaction extent, differences were magnified at intermediate conversion values, so the residence time should be limited. The reaction residence time was fixed to $30 \mathrm{~min}$.

- Temperature: wollastonite reportedly carbonates best when the temperature is sufficiently high to aid in calcium leaching but not so high that it reduces the solubility of $\mathrm{CO}_{2}$ too greatly [45]. 
The temperature choice also impacts the duration of start-up, since heating from room temperature to the reaction temperature takes time, and of shut-down, since the reactor must be sufficiently cooled before it can be depressurized $\left(<100{ }^{\circ} \mathrm{C}\right)$ and before its contents can be drained safely $\left(<80^{\circ} \mathrm{C}\right.$ ). Hence the temperature to be used was $120^{\circ} \mathrm{C}$ (at this temperature, the steam pressure was 0.974 bar, gauge).

- Particle size: particle size is one of the most important parameters for mineral carbonation, as an increase in surface area (i.e., particle size reduction) contributes to the rate of carbonation (Equation (8)). However, reducing the particle size of mined minerals is costly, and the more milling is done, the lower the net $\mathrm{CO}_{2}$ sequestration for the process (the process can even become a net $\mathrm{CO}_{2}$ emitter). The material used in this project was milled by NYCO Minerals to the maximum extent that the company still deems economical for commercialization of the mineral; particle size data is presented in the Appendix. According to the results of Huijgen et al. [45], an average particle size below $100 \mu \mathrm{m}$ is needed for satisfactory kinetics, which is the case for the present material. Hence, the material was used as is, and the initial particle size was constant for all experiments.

Two important process parameters remain for the study of reaction kinetics and mass transfer of wollastonite carbonation: (a) the $\mathrm{CO}_{2}$ partial pressure, and (b) the stirring rate. Based on the findings of Huijgen et al. [45], the following conditions (two factors with four levels) were used in this experimental investigation:

- $\mathrm{CO}_{2}$ gauge pressure (barg): $2,5,10,40$.

- Stirring rate (rpm): 100, 200, 400, 600 .

Based on these parameters, a total of 16 experiments can be performed with unique conditions, according to Factorial Design $\left(4^{2}\right)$. Figure 9 indicates these conditions and highlights the conditions that should preferably be used in this lab to study the effect of the process variables (factors) on the reaction kinetics and mass transfer. Each student group shall use a different set of conditions. It should be noted that students only have time to perform a single experiment in a three-hour period, hence replicating experiments to increase the reliability of the experimental results, while important in the professional and research settings, is not expected for these experiments.

\begin{tabular}{|c|c|c|c|}
\hline$\frac{\underline{\mathrm{E} 8}}{2 \operatorname{barg} \mathrm{CO}_{2}+100 \mathrm{rpm}}$ & 5 barg $\stackrel{\text { E9 }}{\mathrm{CO}_{2}}+100 \mathrm{rpm}$ & 10 barg $\underline{\mathrm{E} 10} \mathrm{CO}_{2}+100 \mathrm{rpm}$ & 40 barg $\stackrel{\text { E7 }}{\mathrm{CO}_{2}}+100 \mathrm{rpm}$ \\
\hline $2 \operatorname{barg} \stackrel{\mathrm{E}}{\mathrm{CO}}+1_{2}+200 \mathrm{rpm}$ & 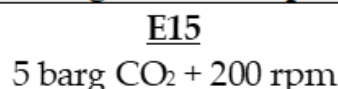 & $10 \mathrm{barg} \stackrel{\mathrm{E} 16}{\mathrm{CO}_{2}}+200 \mathrm{rpm}$ & $40 \mathrm{barg} \stackrel{\mathrm{E} 6}{\mathrm{CO}_{2}}+200 \mathrm{rpm}$ \\
\hline $2 \operatorname{barg}{\stackrel{\mathrm{E} 12}{\mathrm{O}_{2}}+400 \mathrm{rpm}}^{2}$ & 5 barg $\stackrel{\mathrm{E} 13}{\mathrm{CO}_{2}+400 \mathrm{rpm}}$ & 10 barg $\stackrel{\text { E14 }}{\mathrm{CO}_{2}}+400 \mathrm{rpm}$ & 40 barg $\frac{\text { E5 }}{\mathrm{CO}_{2}}+400 \mathrm{rpm}$ \\
\hline 2 barg $\underline{\mathrm{E} 1} \mathrm{CO}_{2}+600 \mathrm{rpm}$ & 5 barg $\frac{\underline{\mathrm{E}} 2}{\mathrm{CO}_{2}+600 \mathrm{rpm}}$ & 10 barg $\underline{\mathrm{CO}_{2}}+600 \mathrm{rpm}$ & 40 barg $\underline{\mathrm{CO}_{2}}+600 \mathrm{rpm}$ \\
\hline
\end{tabular}

Figure 9. Factorial design of experimental variables. Shading indicates the order of preference (darker $=$ greater priority) if less than the full design is tested. Experiment number (e.g., E1) indicates a suggested order.

\subsection{Experimental Procedure}

The experiment would involve high pressure and temperature. Safety precautions should be followed precisely, and caution should be constantly exercised during permanency in the laboratory. In the first step, students should determine operational conditions they would run according to the schedule presented in Figure 9. The following three steps would consist of: loading the reactor; running the reactor; analyzing the product. Complete procedural details that would be followed by the students, in chronological order, are provided in Supplementary_Material_1, along with a data 
table (Table S1) for recording observations and values obtained during the experiment. The duration of each experiment would be approximately 3 hours, and the work would be ideally carried out in groups of 2 or 3 students.

\section{Experimental Investigation Part C: Calculations and Questions}

\subsection{Moisture Content in Collected Filter Cake}

Using the weighing data recorded, calculate the moisture content (MC (\%)) of the filter cake, according to Equation (13), and the total mass of reacted solids collected. If $m_{w s}$ is mass of wet solids (Equation (14)) and $m_{d s}$ is mass of dry solids (Equation (15)), then:

$$
\begin{gathered}
M C=\frac{m_{w s}-m_{d s}}{m_{d s}} \times 100 \\
m_{w s}=\left(m_{C}+m_{F}+m_{R C}\right)-\left(m_{C}+m_{F}\right) \\
m_{d s}=\left(m_{C}+m_{F}+m_{R C}-m_{H_{2} \mathrm{O}}\right)-\left(m_{C}+m_{F}\right)
\end{gathered}
$$

where $m_{C}$ : a mass of crucible; $m_{F}$ : a mass of filter paper; $m_{R C}$ : a mass of remaining cake (after retrieving a sample for titration test); $m_{\mathrm{H}_{2} \mathrm{O}}$ : a mass of moisture. This methodology should be employed when executing the experiment.

\section{2. $\mathrm{CO}_{2}$ Content in Fresh and Carbonated Wollastonite}

Using the acidification data recorded, determine the $\mathrm{CO}_{2}$ content of the original wollastonite as well as the carbonated wollastonite. Report the $\mathrm{CO}_{2}$ content in units of $\mathrm{mg}, \mathrm{CO}_{2} / \mathrm{g}$, wollastonite (Equation (20)) and wt \% (Equation (21)). Then, compared to the theoretical maximum value (in a unit of $\mathrm{mg} / \mathrm{g}$ ), report the fractional extent of carbonation conversion $(\xi(\mathrm{t}))$ from Equation (25).

If $m_{i}$ (Equation (17)) is initial mass of acidification vessel and its contents just before start of reaction, and $m_{f}$ (Equation (18)) is final mass of acidification vessel when reaction between $\mathrm{CaCO}_{3}$ (in the sample ( $\left.\mathrm{m}_{\text {sample }}\right)$ ) and $\mathrm{HCl}$ reaction has been completed, then mass of $\mathrm{CO}_{2}$ lost $\left(m_{\mathrm{CO}_{2}}\right)$ is determined according to Equation (16):

$$
\begin{gathered}
m_{\mathrm{CO}_{2}}=m_{i}-m_{f} \\
m_{i}=\left(m_{\text {test tube }}+m_{\text {sample }}\right)+m_{\mathrm{HCl}} \\
m_{f}=m_{\text {test tube }}+m_{\text {sample }}+m_{\mathrm{HCl}}-m_{\mathrm{CO}_{2}}
\end{gathered}
$$

To calculate the $\mathrm{HCl}$ mass, use the Equation (19), where $V_{\mathrm{HCl}}$ is the volume of $\mathrm{HCl}$ used $(15,000 \mathrm{~mL})$, and $\rho_{\mathrm{HCl}}$ is the density of $6 \mathrm{M} \mathrm{HCl}(1.0939 \mathrm{~g} / \mathrm{mL})$ :

$$
m_{\mathrm{HCl}}=V_{\mathrm{HCl}} \times \rho_{\mathrm{HCl}}
$$

The $\mathrm{CO}_{2}$ content is then calculated as (Equations (20) and (21)):

$$
\begin{gathered}
C_{\mathrm{CO}_{2}}\left(\frac{m g \mathrm{CO}_{2}}{g \text { wollastonite }}\right)=\frac{m_{\mathrm{CO}_{2}}}{m_{\text {sample }}-m_{\mathrm{CO}_{2}}} \\
\mathrm{C}_{\mathrm{CO}_{2}}(w t \%)=\frac{m_{\mathrm{CO}_{2}}}{m_{\text {sample }}} \times 100
\end{gathered}
$$

The fractional extent of carbonation $(\xi(t))$ is calculated taking into account two assumptions: wollastonite mass \% of $\mathrm{CaO} 51.2 \%$, and only calcium carbonate $\left(\mathrm{CaCO}_{3}\right)$ forms (Equation (22)). 
The theoretical maximum concentration of $\mathrm{CO}_{2}$ is defined as the concentration of $\mathrm{CO}_{2}$ present in wollastonite if all $\mathrm{CaO}$ present is converted into $\mathrm{CaCO}_{3}$, as described by Equations (23-25):

$$
\begin{aligned}
& \mathrm{CaO}(s)+\mathrm{CO}_{2}(g) \rightarrow \mathrm{CaCO}_{3}(s) \\
& \mathrm{C}_{\mathrm{CO}_{2}, \text { max }}=\frac{51.2 \mathrm{~g} \mathrm{CaO}}{100 \text { gwollastonite }} \times \frac{1 \mathrm{gmole} \mathrm{CaO}}{56.077 \mathrm{~g} \mathrm{CaO}} \times \frac{1 \text { gmole } \mathrm{CO}_{2}}{1 \text { gmole CaO }} \times \frac{44.009 \mathrm{~g} \mathrm{CO}_{2}}{1 \mathrm{gmole} \mathrm{CO}_{2}} \times \frac{10^{3} \mathrm{mg} \mathrm{CO}}{1 \mathrm{~g} \mathrm{CO}_{2}}=\frac{401.8155 \mathrm{mg} \mathrm{CO}}{\mathrm{g} \text { wollastonite }} \\
& \mathrm{C}_{\mathrm{CO}_{2} \text {,reacted }}=\mathrm{C}_{\mathrm{CO}_{2}}(\text { Carbonated Wollastonite })-\mathrm{C}_{\mathrm{CO}_{2}}(\text { Fresh Wollastonite }) \\
& \xi(t)=\frac{\text { Reacted concentration of } \mathrm{CO}_{2}\left(\frac{m g \mathrm{CO}_{2}}{\mathrm{~g} \text { sample }}\right)}{\text { Theoretical concentration of } \mathrm{CO}_{2}\left(\frac{m g \mathrm{CO}_{2}}{\mathrm{~g} \text { Sample }}\right)}=\frac{\mathrm{C}_{\mathrm{CO}_{2} \text {,reacted }}}{\mathrm{C}_{\mathrm{CO}_{2} \text {, max }}}
\end{aligned}
$$

\subsection{Laboratory Report Questions}

After the initial calculations, the students answer several questions, as part of their experimental investigation report, to evaluate their progress and knowledge. The following is a list of questions used at Sheridan College. Some questions directly relate to the experiment conducted and data collected, while others challenge students to hypothesize based on fundamental engineering concepts and to explore available literature.

1. Present all experimental data in well-formatted lists and/or tables (in addition to the photocopy of your lab notebook notes).

2. Present answers to the calculation questions and show calculations.

3. Comment on your confidence in the acidification results for the original and carbonated solids, and make any additional remark about using this method for $\mathrm{CO}_{2}$ uptake determination.

4. Comment on the carbonation extent achieved. Is it as expected based on the theory on process conditions and mechanism?

5. How can the reaction progress be followed in real-time (on-line)? Research and summarize at least two instrumental methods that can be coupled to a pressurized high-temperature reactor.

6. Would it make any difference to the reaction if impure $\mathrm{CO}_{2}$ was used (e.g. direct flue gas, or $\mathrm{CO}_{2}$ of lower purity than used)? Think about chemical and physical aspects.

7. Explain the function of a rupture disk and how it is selected for a reactor. In what cases is a rupture disk used versus a relief valve?

8. Research literature to find out what the $\mathrm{pH}$ and $\mathrm{CO}_{2}$ solubility $(\mathrm{mol} / \mathrm{L})$ at the operating temperature and pressure you used would be if the reaction medium was pure water (i.e. no mineral).

9. Following up on question 8 , do you think the $\mathrm{pH}$ and $\mathrm{CO}_{2}$ solubility with the reacting wollastonite present (as in the experiment) would be higher or lower than the values you found for pure water?

\section{Discussion}

The experimental investigation presented in this paper was conducted in Summer 2017 for the first time, with three two-member groups of students, as a laboratory assignment in the "Air Pollution Chemistry" course at Sheridan College. However, this conceptualized experiment can be applied in a range of multidisciplinary courses at the 3rd or 4th-year levels in Bachelor or Advanced Diploma programs and the 1st or 2nd-year levels of a Master's program. Suitable courses include titles, such as "Reaction Kinetics", “Reactor Design", "Unit Operations", "Mass Transfer Operations", "Materials Chemistry", among others. It is crucial that students performing the conceptualized lab possess prior knowledge, and preferably laboratory experience, in fundamental topics that include physical chemistry and transport phenomena.

In the first implementation of this methodology, students were required to perform this investigation within an approximately three-hours duration in the laboratory, and write a report (one per student) with the data and results obtained that was due one week after the lab. Lab experiments 
in this course are alternated between groups, so each week one group performed the Accelerated Carbonation lab. As this was the most comprehensive lab students performed in the course, all groups were scheduled to perform the lab during the last three weeks of the course, so that students would be experienced in air pollution experiments before attempting this lab. Students were also required to read the extensive lab procedure before arriving in the lab and were required to show notes they had made in preparation for the lab. This was done to ensure students worked efficiently to be able to conclude the experiment in the allotted time and to ensure students were well aware of the safety precautions that had to be taken. All six students who experimented understood and concluded the experiment in the time proposed, describing the procedures, data, calculations (Sections 4.2 and 4.3) in detail in the report, adequately answering the questions (Section 4.3), and correctly filling out the data table (Table S1). It is thus concluded that the conceptualized experimental investigation has been validated both procedurally and pedagogically. Furthermore, this experimental investigation showed (from the instructor's perspective based on lab performance and quality of reports) that students were more engaged when they had a clear purpose and knew the value of the experimental data.

After the collection of the student's results obtained using different parameter conditions, the reaction efficiency obtained in the experiments, which is the relation between the maximum theoretical and actual experimental $\mathrm{CO}_{2}$ uptake values, was on average $22.5 \%$, ranging from 17 to $28 \%$. These results are in good agreement with those of Huijgen et al. [45]. They reported an efficiency of $39 \%$ for the same reaction duration used herein $(30 \mathrm{~min}$.), and using the following parameters: particle size $<106 \mu \mathrm{m}(\mathrm{D}(4,3)=51.1 \mu \mathrm{m}), \mathrm{T}=150{ }^{\circ} \mathrm{C}, \mathrm{P}_{\mathrm{CO} 2}=20 \mathrm{bar}, \mathrm{L} / \mathrm{S}=5 \mathrm{~kg} / \mathrm{kg}, 500 \mathrm{rpm}$. The higher efficiency obtained in that study compared to the students' results could be attributed primarily to the particle size. The students used material with $75 \mathrm{wt} \%$ having particle size below $100 \mu \mathrm{m}$ and $\mathrm{D}(4,3)$ equal to $82.7 \mu \mathrm{m}$. Thus, it was expected that the students' coarser material would carbonate less in the same reaction duration, and hence could be said that their results were adequate.

The fact that all groups obtained reasonable efficiency values is also evidence that students not only performed the experiments adequately but were able to apply the required calculations correctly, even though such calculations were different from the calculations they performed in prior labs. Strong student performance in this experimental lab is evidence of strong student engagement. Student engagement was also verified by inspecting their laboratory procedures at the beginning of the lab period. Students were asked to highlight and make hand-written notes on the procedure before coming to the lab to be well prepared, and all students turned up with significantly marked up copies of the procedure.

Students were also able to provide thoughtful answers to the questions presented in Section 4.3; the following are some examples of the answers provided for selected questions:

Q3) Students commented on the increase in the $\mathrm{CO}_{2}$ content of wollastonite after reaction versus the original mineral. Comments were also made regarding possible vapor losses from the acidification tube due to heating, and water condensation into the tube due to an ice bath, as potential sources of error in the quantitative determination.

Q5) Two approaches to follow reaction progress in real-time were commonly mentioned. One is to use instrumentation that analyzes the reaction medium in-situ, such as in-situ FTIR. The other is by collecting samples while the reactor operates at elevated temperatures and pressures, using appropriate sampling techniques.

Q6) Students recalled the concepts of partial and total pressures to answer this question. They realized that it is the $\mathrm{CO}_{2}$ partial pressure that drives the carbonation reaction, thus impure $\mathrm{CO}_{2}$, in the form of flue gases, would require greater total pressure to achieve similar reactivity as pure $\mathrm{CO}_{2}$. From a physical perspective, the implication of this includes the need for reactors that can withstand higher pressures and compressors that can pressure flue gases to very high pressures, both of which affect process costing.

Q7) This question about rupture disks and relief valves can easily be answered by searching the internet, but it was selected for this lab for a special purpose. Sheridan students perform another 
lab experiment using a climbing film evaporator, which uses a boiler that has a pressure relief valve. Thus answering this question enabled the students to recall that experiential learning event, which is a pedagogical approach to reinforce learned concepts, thus making the experience of researching the answer to this question more engaging.

Q8) The answer to this question comes from published literature and can be most readily be found in journal articles. This question is thus designed to expose students to journal literature, and an example of a paper that students found to answer this question is that of Duan and Sun [63].

Q9) Students analyzed the effect of wollastonite on $\mathrm{CO}_{2}$ solubility, and consequently $\mathrm{pH}$, by looking at chemical equilibrium equations. They verified that wollastonite consumes acidity, thus shifts the carbonic acid equilibria towards the greater dissolution of $\mathrm{CO}_{2}$ and increases the $\mathrm{pH}$.

It is also worth briefly discussing the potential industrial implementation of wollastonite mineral carbonation, given the results obtained by the students, and those reported in the literature. The students achieved up to $28 \%$ calcium conversion efficiency with $30 \mathrm{~min}$ duration, and Huijgen et al [45] reported a value of $45 \%$ with $60 \mathrm{~min}$ duration (using the aforementioned parameters). For industry, close to $100 \%$ efficiency would be desirable, to maximize the $\mathrm{CO}_{2}$ sequestration potential of the technology and to minimize the expenditure on wollastonite mineral. Full conversion of minerals is not commonly reported in the literature because of the long durations required and other conversion limiting factors (e.g., passivation). Santos et al. [64] have reported full conversion of olivine $\left(0.515 \mathrm{~g}, \mathrm{CO}_{2} / \mathrm{g}\right.$, olivine $=99.0 \% \pm 3.9 \%$, which is a magnesium-based natural silicate, by carbonating it for $72 \mathrm{~h}$ at $200{ }^{\circ} \mathrm{C}$ and 35 bar $\mathrm{P}_{\mathrm{CO} 2}$, with the addition of $1 \mathrm{M} \mathrm{NaCl}$ and $\mathrm{L} / \mathrm{S}=4$. From an industrial perspective, long durations ( $>$ few hours) would not be feasible due to throughput and energy demand limitation; thus, it is important to assess with partial conversion at reasonable durations to make it an industrially implementable process. This can be done by performing energy analyses, such as that discussed in Section 5.1.

Going back to the conceptualized two-stages project, the experimental results presented by each work are to be combined to yield a dataset that can be applied in the subsequent design project. In the design project, students would use the experimental data obtained by themselves and classmates on the accelerated mineral carbonation of wollastonite, to determine if this is a feasible process for industry to sequester carbon dioxide, in view of mitigating climate change. Also, they would use the experimental data, acquired using a range of process conditions, to study the effect of the process variables $\left(\mathrm{CO}_{2}\right.$ pressure and mixing rate) on the carbonation kinetics and mass transfer rate. When students receive the dataset, they would carefully inspect the experimental data to investigate if any of the data is not reliable, either due to experimental or data processing error. If the error is correctable, students would be encouraged to do so; otherwise, they would use their engineering know-how to discard outliers. Students should be mindful that each data point would not be replicated (as each group runs a different condition), so they should observe and foresee trends in the data for signs of unreliable data.

The first step of the design project is to be done by way of an energetic analysis, whereby students would design a process flowsheet to sequester $\mathrm{CO}_{2}$, determine how much energy it will consume to perform this task, and assess if the $\mathrm{CO}_{2}$-intensity of the process is low enough so that it can achieve net $\mathrm{CO}_{2}$ sequestration. The second step is to be done by way of data analysis and modeling. The effect of pressure at constant mixing rate will enable finding a rate law that predicts reaction kinetics as a function of pressure. The effect of the mixing rate at constant pressure will enable determining if the mass transfer of calcium ions from the mineral particles to the bulk solution, where they precipitate as carbonate, is dominated by diffusion or convection, and if the latter, how much benefit increasing the rate of mixing brings to the carbonation rate. Section 5.1 and Supplementary_Material_2 provide more details on the design project requirements and procedure that would be (or could be) provided to students. 


\subsection{Energetic Analysis and Design Project}

One of the biggest concerns with the accelerated mineral carbonation technology is that if it implemented as an industrial process, it will not deliver net $\mathrm{CO}_{2}$ sequestration. The reason behind this is that all process equipment in the industry requires energy to function, and, in most cases, that energy is supplied from $\mathrm{CO}_{2}$-intensive processes. Even so-called "green energy" has a $\mathrm{CO}_{2}$ footprint. Hydroelectric fares the best, at $4 \mathrm{~g}, \mathrm{CO}_{2}-\mathrm{eq} / \mathrm{kWh}_{\mathrm{e}}$, while wind and solar emit (over the life-cycle) 12 and $22 \mathrm{~g}, \mathrm{CO}_{2}$-eq/ $\mathrm{kWh}$, respectively $\left(\mathrm{CO}_{2}\right.$-eq stands for $\mathrm{CO}_{2}$-equivalent, and $\mathrm{kWh}_{\mathrm{e}}$ is the rate of electrical energy generation) [65]. At the other end of the spectrum, the median $\mathrm{CO}_{2}$ intensity of coal power generation, the worst performer, is a whopping $1001 \mathrm{~g}, \mathrm{CO}_{2}-\mathrm{eq} / \mathrm{kWh}_{\mathrm{e}}$. Thus, if too much energy is used for accelerating mineral carbonation, the process may end up emitting more $\mathrm{CO}_{2}$ than sequestering it.

Due to the energetic challenges posed, it is vital to conduct an energetic analysis of any proposed accelerated mineral carbonation process. For example, Santos et al. [66] found that, for an ultrasound-enhanced mineral carbonation process (at lab-scale), for every $2.3 \mathrm{~g}$ of $\mathrm{CO}_{2}$ sequestered, $79.2 \mathrm{~g}$ would be emitted (based on the energy-mix of Belgium). They proposed some strategies to reduce the $\mathrm{CO}_{2}$ emissions further at the industrial-scale, such as securing a less $\mathrm{CO}_{2}$-intensive energy source, increasing the solids loading in the reactor (i.e., more solids per volume of liquid), and improving the design of the reactor to maximize the utilization of sonication energy. Still, a 100-factor reduction in $\mathrm{CO}_{2}$-intensity would be necessary to achieve net $\mathrm{CO}_{2}$ sequestration, so it is not easy and perhaps not feasible.

More recently, for a more conventional carbonation process, utilizing steelmaking slag as the carbon sink, Costa et al. [67] estimated an energy requirement of $272-1750 \mathrm{kWh} / \mathrm{tonne} \mathrm{CO}_{2}$ sequestered. Based on the aforementioned energy-intensity of wind power generation, this would represent $38 \mathrm{~kg}$, $\mathrm{CO}_{2}$ emitted per $1000 \mathrm{~kg}, \mathrm{CO}_{2}$ sequestered. Hence, this would be a feasible process for net $\mathrm{CO}_{2}$ sequestration. It should be noted, however, that steelmaking slags require less intense carbonation conditions compared to wollastonite (as the material is more reactive). Unfortunately, there is far less steelmaking slag being produced than $\mathrm{CO}_{2}$ being emitted by steelmaking, so this material alone cannot substantially reduce emissions from this $\mathrm{CO}_{2}$-intensive industry. Thus, natural materials, such as wollastonite, more abundantly available (though more expensive due to mining and transportation costs), are required to curtail industrial emissions.

So the question is, can accelerated carbonation of wollastonite become a feasible industrial process for net $\mathrm{CO}_{2}$ sequestration? This would be addressed in the design project, that should include the following analyses:

- Energetic analysis: (a) explain how you adapted the proposed procedure to reach the energy consumption and net $\mathrm{CO}_{2}$ sequestration results (what assumptions had to be made, what changes you made, if any, to the proposed procedure, etc.); (b) show values (and sources) of all parameters used in the equations; (c) show the energy consumption value of each individual process/equipment; (d) show the calculation procedure of converting energy consumption to $\mathrm{CO}_{2}$ emissions (footprint) and compare the $\mathrm{CO}_{2}$ emissions rate to the $\mathrm{CO}_{2}$ sequestration rate to determine if net $\mathrm{CO}_{2}$ sequestration is achieved; (e) discuss what process changes you may make, if more experimental or modeling information, to improve the efficiency of the process; (f) write conclusions and recommendations on whether accelerated mineral carbonation can become an industrially feasible process for $\mathrm{CO}_{2}$ sequestration.

- Reaction rate law: (a) explain the procedure used to develop the rate law(s), including data and graphs used; (b) explain assumptions taken and any limitation of the applicability of the rate law(s); (c) comment on what you learned about the mineral carbonation reaction based on the rate law(s) obtained; (d) comment on how the rate law(s) can aid in improving the process design and energy consumption presented earlier. 
- Mass transfer analysis: (a) explain the procedure used in the analysis, including data and graphs used; (b) explain assumptions taken and any limitation on validity of the analysis results; (c) comment on what you learned about the mineral carbonation reaction based on the results obtained; (d) comment on how the analysis can aid in improving the process design and energy consumption presented earlier.

More detail on the design procedure can be found in Supplementary_Material_2.

\section{Conclusions}

The experimental approach and formulas presented in this work demonstrated a potential pedagogic complement, introducing students to the mineral carbonation process and helping to increase interest in this subject. This methodology is easy to apply, with the possibility of different types of reactor available in the market and minerals (i.e., olivine, serpentine, etc.) or residues (i.e., ashes, tailings, and slags) and could be used to expose students to an environmental concept and engage into opportunities of application of this technology with the visible results obtained after the investigation.

After working in small groups, the learning outcomes for this practical experiment are that students should also be able to design experiments, to test a hypothesis, and work in groups to solve a shared problem. This work demonstrates the importance of the practical investigation to get a deeper understanding and engage students in chemical engineering or other courses related to applied chemistry.

Supplementary Materials: The following are available online at http://www.mdpi.com/2071-1050/11/15/4156/s1, Supplementary_Material_1 and Supplementary_Material_2.

Author Contributions: Conceptualization, R.M.S.; Methodology, R.M.S., J.S.S.; Validation, J.S.S.; Writing一Original Draft Preparation, H.F., R.M.S.; Writing-Review and Editing, R.M.S.; Supervision, R.M.S.

Funding: The work of H.F. and the APC were funded by a Barrett Sustainable Food Engineering Grant (Barrett2018-14) at the University of Guelph, and the work of J.S.S. was funded by a Scholarship, Research and Creative Activities Growth Grant at Sheridan College.

Acknowledgments: The authors are grateful to the assistance provided by Terence Davison, Nausheen Zehra, Daniel Liao, and Jaspreet Chauhan at Sheridan College to make it possible to develop the laboratory experiment. R.M.S. is also thankful for the funding provided by Sheridan College that covered the Co-op stipend of J.S.S., for the funding provided by the Barrett Family that covered the research assistantship stipend of H.F., and to the Teaching and Learning Academy program at Sheridan College for initially incentivizing this work.

Conflicts of Interest: The authors declare no conflict of interest.

\section{Appendix A}

The mineralogical composition of the wollastonite material was determined by XRD. The diffractogram is presented in Figure A1. The diffraction peaks match well with those of wollastonite $1 \mathrm{~A}$ (the most common polymorph of $\mathrm{CaSiO}_{3}$, which crystallizes in the triclinic system). Quantification by Rietveld Refinement indicates the presence of $82 \mathrm{wt} \%$ wollastonite, with minor quantities of quartz $\left(\mathrm{SiO}_{2}\right)$, portlandite $\left(\mathrm{Ca}(\mathrm{OH})_{2}\right)$, and merwinite $\left(\mathrm{MgCa}_{3}\left(\mathrm{SiO}_{4}\right)_{2}\right)$. The $\mathrm{pH}$ of a wollastonite material-water slurry at a liquid-to-solid ratio of $10 \mathrm{~kg} / \mathrm{kg}$ was determined to be 10.6 , after $24 \mathrm{~h}$ shaking, which is close to the theoretical value for wollastonite of 10.7 .

The particle size distribution of the wollastonite material was determined by wet Laser Diffraction Analysis (LDA) and is presented in Figure A2. The material has a relatively wide particle size distribution (as observed in Figure 1), ranging from sub-micron to $\sim 600 \mu \mathrm{m}$, which partly owes to the acicular shape of the material (i.e., a combination of long needles and small needle fragments). The average particle size $(\mathrm{D}(4,3))$ of this material was $82.7 \mu \mathrm{m}$, with a $\mathrm{D}_{50}$ (median diameter) by volume of $44.5 \mu \mathrm{m}$. The specific surface area (SSA) was determined to be $0.8903 \mathrm{~m}^{2} / \mathrm{g}$. 


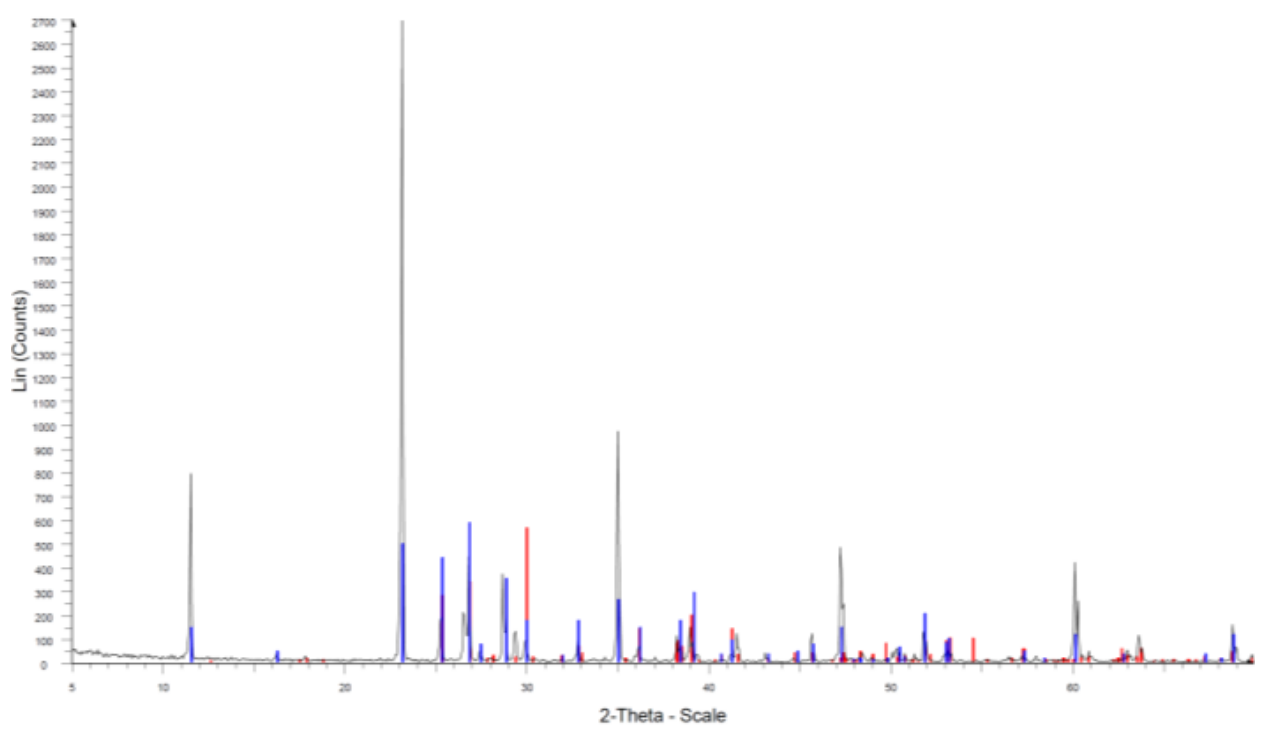

Figure A1. X-ray diffractogram of wollastonite material; wollastonite mineral peaks indicated by colored lines $($ red $=$ wollastonite $2 \mathrm{M}$; blue $=$ wollastonite $1 \mathrm{~A})$.

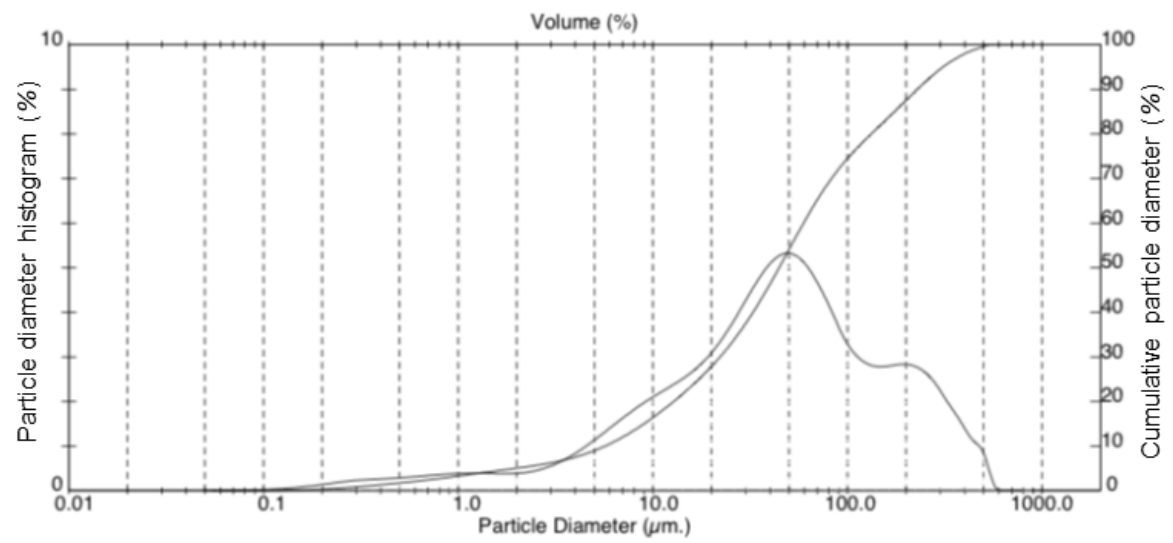

Figure A2. The particle size distribution of wollastonite material, determined by LDA (Laser Diffraction Analysis).

\section{References}

1. UNESCO. United nations educational, scientific and cultural organization: Educating for a sustainable future: A transdisciplinary vision for concerted action. In Proceedings of the International Conference on Environment and Society: Education and Public Awareness for Sustainability, Thessalonika, Greece, 8-12 December 1997.

2. Anastas, P.T.; Warner, J.C. Green Chemistry: Theory and Practice, 12 Principles of Green Chemistry; Oxford University Press: New York, NY, USA, 1998.

3. Bastin, L.D.; Dicks, A.P. Advances in green chemistry education. Green Chem. Lett. Rev. 2019, $12,101$. [CrossRef]

4. Summerton, L.; Hurst, G.A.; Clark, J.H. Facilitating active learning within green chemistry. Curr. Opin. Green Sustain. Chem. 2018, 13, 56-60. [CrossRef]

5. Dicks, A.P. Teaching reaction efficiency through the lens of green chemistry: Should students focus on the yield, or the process? Curr. Opin. Green Sustain. Chem. 2018, 13, 27-31. [CrossRef]

6. Dym, C.L.; Agogino, A.M.; Eris, O.; Frey, D.D.; Leifer, L.J. Engineering Design Thinking, Teaching, and Learning. J. Eng. Educ. 2005, 94, 103-120. [CrossRef]

7. Eilks, I.; Byers, B. (Eds.) Innovative Methods of Teaching and Learning Chemistry in Higher Education; RSC Publishing: Cambridge, UK, 2009. 
8. Feisel, L.D.; Rosa, A.J. The Role of the Laboratory in Undergraduate Engineering Education. J. Eng. Educ. 2005, 94, 121-130. [CrossRef]

9. Martínez, K.P.; Campos, J.L.B. Developing scientific thinking skills through teaching chemical reaction with inquiry based teaching. Educ. Quím. 2019, 30, 93. [CrossRef]

10. McKim, A.S. Overcoming sustainability barriers within the chemical industry. Curr. Opin. Green Sustain. Chem. 2018, 14, 10-13. [CrossRef]

11. Parmentier, M.; Gabriel, C.M.; Guo, P.; Isley, N.A.; Zhou, J.; Gallou, F. Switching from organic solvents to water at an industrial scale. Curr. Opin. Green Sustain. Chem. 2017, 7, 13-17. [CrossRef]

12. Metz, B.; Davidson, O.; de Coninck, H.; Loos, M.; Meyer, L. (Eds.) IPCC Special Report on Carbon Dioxide Capture and Storage; Cambridge University Press: New York, NY, USA, 2005.

13. Oelkers, E.H.; Gislason, S.R.; Matter, J. Mineral Carbonation of $\mathrm{CO}_{2}$. Elements 2008, 4, 333-337. [CrossRef]

14. Saran, R.K.; Arora, V.; Yadav, S. $\mathrm{CO}_{2}$ sequestration by mineral carbonation: A review. Glob. Nest J. 2018, 20, 497-503. [CrossRef]

15. Baena-Moreno, F.M.; Rodríguez-Galán, M.; Vega, F.; Alonso-Fariñas, B.; Vilches Arenas, L.F.; Navarrete, B. Carbon capture and utilization technologies: A literature review and recent advances. Energy Sources, Part A Recover. Util. Environ. Eff. 2019, 41, 1403-1433. [CrossRef]

16. Kelektsoglou, K. Carbon capture and storage: A review of mineral storage of $\mathrm{CO}_{2}$ in Greece. Sustainability 2018, 10, 4400. [CrossRef]

17. National Oceanic and Atmospheric Administration (NOAA). Available online: https://www.noaa.gov (accessed on 18 May 2019).

18. The Intergovernmental Panel on Climate Change (IPCC). Summary for Policymakers. In Climate Change 2014: Mitigation of Climate Change. Contribution of Working Group III to the Fifth Assessment Report of the Intergovernmental Panel on Climate Change; Edenhofer, O., Pichs-Madruga, R., Sokona, Y., Farahani, E., Kadner, S., Seyboth, K., Adler, A., Baum, I., Brunner, S., Eickemeier, P., et al., Eds.; Cambridge University Press: Cambridge, UK; New York, NY, USA, 2014.

19. Georgakopoulos, E.; Santos, R.M.; Chiang, Y.W.; Manovic, V. Two-way Valorization of Blast Furnace Slag: Synthesis of Precipitated Calcium Carbonate and Zeolitic Heavy Metal Adsorbent. J. Vis. Exp. 2017, 120, e55062. [CrossRef] [PubMed]

20. Azadi, M.; Edraki, M.; Farhang, F.; Ahn, J. Opportunities for mineral carbonation in Australia's mining industry. Sustainability 2019, 11, 1250. [CrossRef]

21. Ibrahim, M.; El-Naas, M.; Benamor, A.; Al-Sobhi, S.; Zhang, Z. Carbon Mineralization by Reaction with Steel-Making Waste: A Review. Processes 2019, 7, 115. [CrossRef]

22. Dindi, A.; Quang, D.V.; Vega, L.F.; Nashef, E.; Abu-Zahra, M.R.M. Applications of fly ash for $\mathrm{CO}_{2}$ capture, utilization, and storage. J. CO 2 Util. 2019, 29, 82-102. [CrossRef]

23. Carbon cure Technologies. Available online: https://www.carboncure.com/ (accessed on 28 June 2019).

24. Carbon8 Systems. Available online: http://c8s.co.uk/ (accessed on 28 June 2019).

25. Mineral Carbonation International. Available online: https://www.mineralcarbonation.com/ (accessed on 28 June 2019).

26. Solidia Technologies. Available online: https://solidiatech.com/ (accessed on 28 June 2019).

27. Olajire, A.A. A review of mineral carbonation technology in sequestration of $\mathrm{CO}_{2}$. J. Pet. Sci. Eng. 2013, 109, 364-392. [CrossRef]

28. Li, J.; Jacobs, A.D.; Hitch, M. Direct aqueous carbonation on olivine at a $\mathrm{CO}_{2}$ partial pressure of $6.5 \mathrm{MPa}$. Energy 2019, 173, 902-910. [CrossRef]

29. Farhang, F.; Oliver, T.K.; Rayson, M.S.; Brent, G.F.; Molloy, T.S.; Stockenhuber, M.; Kennedy, E.M. Dissolution of heat activated serpentine for $\mathrm{CO}_{2}$ sequestration: The effect of silica precipitation at different temperature and $\mathrm{pH}$ values. J. $\mathrm{CO}_{2}$ Util. 2019, 30, 123-129. [CrossRef]

30. Haque, F.; Santos, R.M.; Dutta, A.; Thimmanagari, M.; Chiang, Y.W. Co-Benefits of Wollastonite Weathering in Agriculture: $\mathrm{CO}_{2}$ Sequestration and Promoted Plant Growth. ACS Omega 2019, 4, 1425-1433. [CrossRef]

31. Stopic, S.; Dertmann, C.; Modolo, G.; Kegler, P.; Neumeier, S.; Kremer, D.; Wotruba, H.; Etzold, S.; Telle, R.; Rosani, D.; et al. Synthesis of Magnesium Carbonate via Carbonation under High Pressure in an Autoclave. Metals 2018, 8, 993. [CrossRef] 
32. Nowamooz, A.; Dupuis, J.C.; Beaudoin, G.; Molson, J.; Lemieux, J.M.; Horswill, M.; Fortier, R.; Larachi, F.; Maldague, X.; Constantin, M.; et al. Atmospheric Carbon Mineralization in an Industrial-Scale Chrysotile Mining Waste Pile. Environ. Sci. Technol. 2018, 52, 8050-8057. [CrossRef] [PubMed]

33. Kim, H.-J.; Lee, H.-K. Mineral Sequestration of Carbon Dioxide in Circulating Fluidized Bed Combustion Boiler Bottom Ash. Minerals 2017, 7, 237. [CrossRef]

34. Haque, F.; Chiang, E.; Santos, R.M. Alkaline Mineral Soil Amendment: A Climate Change 'Stabilization Wedge'? Energies 2019, 12, 2299. [CrossRef]

35. Casiflux F Technical Data; Sibelco Specialty Minerals Europe: Antwerp, Belgium, 2011.

36. Daval, D.; Martinez, I.; Corvisier, J.; Findling, N.; Goffé, B.; Guyot, F. Carbonation of Ca-bearing silicates, the case of wollastonite: Experimental investigations and kinetic modeling. Chem. Geol. 2009, 265, 63-78. [CrossRef]

37. Liu, W.; Song, L.; Xu, C.; Rohani, S.; Chen, M.; Liang, B.; Li, C. Combined synthesis of $\mathrm{Li}_{4} \mathrm{SiO}_{4}$ sorbent with high $\mathrm{CO}_{2}$ uptake in the indirect carbonation of blast furnace slag process. Chem. Eng. J. 2019, 370, 71-80. [CrossRef]

38. Rashid, M.I.; Benhelal, E.; Farhang, F.; Oliver, T.K.; Rayson, M.S.; Brent, G.F.; Stockenhuber, M.; Kennedy, E.M. Development of Concurrent grinding for application in aqueous mineral carbonation. J. Clean. Prod. 2019, 212, 151-161. [CrossRef]

39. Rigopoulos, I.; Ioannou, I.; Delimitis, A.; Efstathiou, A.; Kyratsi, T. Ball Milling Effect on the $\mathrm{CO}_{2}$ Uptake of Mafic and Ultramafic Rocks: A Review. Geosciences 2018, 8, 406. [CrossRef]

40. Wang, F.; Dreisinger, D.B.; Jarvis, M.; Hitchins, T. The technology of $\mathrm{CO}_{2}$ sequestration by mineral carbonation: Current status and future prospects. Can. Metall. Q. 2018, 57, 46-58. [CrossRef]

41. Dudhaiya, A.; Santos, R.M. How Characterization of Particle Size Distribution Pre- and Post-Reaction Provides Mechanistic Insights into Mineral Carbonation. Geosciences 2018, 8, 260. [CrossRef]

42. Ptáček, P.; Nosková, M.; Brandštetr, J.; Šoukal, F.; Opravil, T. Mechanism and kinetics of wollastonite fibre dissolution in the aqueous solution of acetic acid. Powder Technol. 2011, 206, 338-344. [CrossRef]

43. Georgakopoulos, E.; Santos, R.M.; Chiang, Y.W.; Manovic, V. Influence of process parameters on carbonation rate and conversion of steelmaking slags-Introduction of the 'carbonation weathering rate'. Greenhouse Gases Sci. Technol. 2016, 6, 470-491. [CrossRef]

44. Daval, D.; Martinez, I.; Guigner, J.-M.; Hellmann, R.; Corvisier, J.; Findling, N.; Dominici, C.; Goffé, B.; Guyot, F. Mechanism of wollastonite carbonation deduced from micro- to nanometer length scale observations. Am. Mineral. 2009, 94, 1707-1726. [CrossRef]

45. Huijgen, W.J.J.; Witkamp, G.J.; Comans, R.N.J. Mechanisms of aqueous wollastonite carbonation as a possible $\mathrm{CO}_{2}$ sequestration process. Chem. Eng. Sci. 2006, 64, 4242-4251. [CrossRef]

46. Peuble, S.; Godard, M.; Gouze, P.; Leprovost, R.; Martinez, I.; Shilobreeva, S. Control of $\mathrm{CO}_{2}$ on flow and reaction paths in olivine-dominated basements: An experimental study. Geochim. Cosmochim. Acta 2019, 252, 16-38. [CrossRef]

47. Zhao, Q.; Liu, C.J.; Jiang, M.F.; Saxén, H.; Zevenhoven, R. Preparation of magnesium hydroxide from serpentinite by sulfuric acid leaching for $\mathrm{CO}_{2}$ mineral carbonation. Miner. Eng. 2015, 79, 116-124. [CrossRef]

48. Abu Fara, A.; Rayson, M.R.; Brent, G.F.; Oliver, T.K.; Stockenhuber, M.; Kennedy, E.M. Formation of magnesite and hydromagnesite from direct aqueous carbonation of thermally activated lizardite. Environ. Prog. Sustain. Energy 2019. [CrossRef]

49. Helgeson, H.C. Kinetics of mass transfer among silicates and aqueous solutions. Geochim. Cosmochim. Acta 1971, 35, 421-469. [CrossRef]

50. Bodor, M.; Santos, R.M.; Kriskova, L.; Elsen, J.; Vlad, M.; Van Gerven, T. Susceptibility of mineral phases of steel slags towards carbonation: Mineralogical, morphological and chemical assessment. Eur. J. Mineral. 2013, 25, 533-549. [CrossRef]

51. Santos, R.M.; Van Bouwel, J.; Vandevelde, E.; Mertens, G.; Elsen, J.; Van Gerven, T. Accelerated mineral carbonation of stainless steel slags for $\mathrm{CO}_{2}$ storage and waste valorization: Effect of process parameters on geochemical properties. Int. J. Greenhouse Gas Control 2013, 17, 32-45. [CrossRef]

52. Santos, R.M.; Thijs, J.; Georgakopoulos, E.; Chiang, Y.W.; Creemers, A.; Van Gerven, T. Improving the Yield of Sonochemical Precipitated Aragonite Synthesis by Scaling up Intensified Conditions. Chem. Eng. Commun. 2016, 203, 1671-1680. [CrossRef]

53. Faust, G.T. Thermal analysis studies on carbonates I. aragonite and calcite. Am. Mineral. 1950, 35, $207-224$. 
54. Santos, R.M.; Bodor, M.; Dragomir, P.N.; Vraciu, A.; Vlad, M.; Gerven, T.V. Magnesium chloride as a leaching and aragonite-promoting self-regenerative additive for the mineral carbonation of calcium-rich materials. Miner. Eng. 2014, 59, 71-81. [CrossRef]

55. Santos, R.M.; Ling, D.; Sarvaramini, A.; Guo, M.; Elsen, J.; Larachi, F.; Beaudoin, G.; Blanpain, B.; Van Gerven, T. Stabilization of basic oxygen furnace slag by hot-stage carbonation treatment. Chem. Eng. J. 2012, 203, 239-250. [CrossRef]

56. Apesteguia, M.; Plante, A.F.; Virto, I. Methods assessment for organic and inorganic carbon quantification in calcareous soils of the Mediterranean region. Geoderma Reg. 2018, 12, 39-48. [CrossRef]

57. Fonnesbeck, B.B.; Boettinger, J.L.; Lawley, J.R. Improving a Simple Pressure-Calcimeter Method for Inorganic Carbon Analysis. Soil Sci. Soc. Am. J. 2013, 77, 1553-1562. [CrossRef]

58. Rajesh, R.; Brindha, K.; Elango, L. Groundwater Quality and its Hydrochemical Characteristics in a Shallow Weathered Rock Aquifer of Southern India. Water Qual. Expo. Heal. 2015, 7, 515-524. [CrossRef]

59. Harvey, D. Section 9.2: Acid-Base Titrations. Modern Analytical Chemistry 2.0. Available online: http: //dpuadweb.depauw.edu/harvey_web/eTextProject/pdfFiles/AnalChem2.0.pdf (accessed on 25 July 2019).

60. Fagerlund, J.; Son, M. Gasometric determination of $\mathrm{CO}_{2}$ released from carbonate materials. J. Chem. Educ. 2010, 87, 1372-1376. [CrossRef]

61. Bajpai, P. Pulping Calculations. In Biermann's Handbook of Pulp and Paper, 3rd ed; Elsevier: Dehradun, India, 2018; Volume 1, pp. 353-373.

62. Khaitan, S.; Dzombak, D.A.; Lowry, G.V. Chemistry of the Acid Neutralization Capacity of Bauxite Residue. Environ. Eng. Sci. 2009, 26, 873-881. [CrossRef]

63. Duan, Z.; Sun, R. An improved model calculating $\mathrm{CO}_{2}$ solubility in pure water and aqueous $\mathrm{NaCl}$ solutions from 273 to $533 \mathrm{~K}$ and from 0 to 2000 bar. Chem. Geol. 2003, 193, 257-271. [CrossRef]

64. Santos, R.M.; Van Audenaerde, A.; Chiang, Y.W.; Iacobescu, R.I.; Knops, P.; Van Gerven, T. Nickel Extraction from Olivine: Effect of Carbonation Pre-Treatment. Metals 2015, 5, 1620-1644. [CrossRef]

65. Moomaw, W.; Burgherr, P.; Heath, G.; Lenzen, M.; Nyboer, J.; Verbruggen, A. Annex II: Methodology. In IPCC Special Report on Renewable Energy Sources and Climate Change Mitigation; Edenhofer, O., Pichs-Madruga, R., Sokona, Y., Seyboth, K., Matschoss, P., Kadner, S., Zwickel, T., Eickemeier, P., Hansen, G., Schlömer, S., et al., Eds.; Cambridge University Press: Cambridge, UK; New York, NY, USA, 2011.

66. Santos, R.M.; Francois, D.; Mertens, G.; Elsen, J.; Van Gerven, T. Ultrasound-intensified mineral carbonation. Appl. Therm. Eng. 2013, 57, 154-163. [CrossRef]

67. Costa, G.; Polettini, A.; Pomi, R.; Stramazzo, A.; Zingaretti, D. Energetic assessment of $\mathrm{CO}_{2}$ sequestration through slurry carbonation of steel slag: A factorial study. Greenhouse Gases Sci. Technol. 2016, 7, 530-541. [CrossRef]

(C) 2019 by the authors. Licensee MDPI, Basel, Switzerland. This article is an open access article distributed under the terms and conditions of the Creative Commons Attribution (CC BY) license (http://creativecommons.org/licenses/by/4.0/). 